\title{
Structured and disordered regions of Ataxin-2 contribute differently to the specificity
} and efficiency of mRNP granule formation.

Arnas Petrauskas $^{1 *}$, Daniel L. Fortunati ${ }^{1 *}$, Amanjot Singh ${ }^{2}$, Arvind Reddy Kandi ${ }^{5}$, Sai Shruti

Pothapragada $^{2}$, Khushboo Agrawal ${ }^{3,4}$, Joern Huelsmeier ${ }^{1}$, Jens Hillebrand ${ }^{1}$, Georgia Brown ${ }^{1}$,

Dhananjay Chaturvedi ${ }^{2}$, Jongbo Lee ${ }^{6}$, Chunghun Lim ${ }^{6}$, Georg Auburger ${ }^{7}, \mathrm{~K}$.

VijayRaghavan $^{2}$, Mani Ramaswami ${ }^{1,2 \dagger}$ and Baskar Bakthavachalu ${ }^{3,5 \dagger}$.

${ }^{1}$ Trinity College Institute of Neuroscience, School of Genetics and Microbiology, Smurfit Institute of Genetics and School of Natural Sciences, Trinity College Dublin, Dublin-2 Ireland. ${ }^{2}$ National Centre for Biological Sciences, TIFR, Bangalore 560065, India. ${ }^{3}$ Tata Institute for Genetics and Society Centre at inStem, Bellary Road, Bangalore 560065, India. ${ }^{4}$ School of Biotechnology, Amrita Vishwa Vidyapeetham of Technology, Mandi 175005, India. ${ }^{6}$ Department of Biological Sciences, Ulsan

*These authors contributed equally to this work.

\section{$\dagger$ Correspondence:}

mani.ramaswami@tcd.ie; Phone+353 (1) 8968400

baskar@iitmandi.ac.in; Phone +91-1905-267705

Running Title: Ataxin-2 PAM2:PABP interactions specify granule composition

Keywords: Ataxin-2, TRIBE, mRNA, PABP, Disordered Regions, Subcellular Organization, 
ABSTRACT:

Ataxin-2 (ATXN2) is a gene implicated in spinocerebellar ataxia type II (SCA2), amyotrophic lateral sclerosis (ALS) and Parkinsonism. The encoded protein is a therapeutic target for ALS and related conditions. ATXN2 (or Atx2 in insects) can function in translational activation, translational repression, mRNA stability and in the assembly of mRNP-granules, a process mediated by intrinsically disordered regions (IDRs). Previous work has shown that the LSm (Like-Sm) domain of Atx2, which can help stimulate mRNA translation, antagonizes mRNP-granule assembly. Here we advance these findings through a series of experiments on Drosophila and human Ataxin-2 proteins. Results of Targets of RNABinding Proteins Identified by Editing (TRIBE), co-localization and immunoprecipitation experiments indicate that a polyA-binding protein (PABP) interacting, PAM2 motif of Ataxin2 may be a major determinant of the mRNA and protein content of Ataxin-2 mRNP granules. Transgenic experiments in Drosophila indicate that while the Atx2-LSm domain may protect against neurodegeneration, structured PAM2- and unstructured IDRinteractions both support Atx2-induced cytotoxicity. Taken together, the data lead to a proposal for how Ataxin-2 interactions are remodelled during translational control and how structured and non-structured interactions contribute differently to the specificity and efficiency of RNP granule condensation as well as to neurodegeneration. 
INTRODUCTION:

53

mRNP granules are intriguing, dynamic membrane-less organelles containing translationally repressed mRNAs, RNA-binding proteins (RBPs), molecular chaperones and a variety of other cellular proteins (Buchan, 2014; Formicola et al, 2019; Kiebler \& Bassell, 2006; Knowles et al, 1996; Martin \& Ephrussi, 2009). The formation and composition of mRNP assemblies are determined by base-pairing interactions between mRNAs, protein-protein interactions and RBP-RNA interactions, whose respective contributions may vary across granule types and physiological states (Bevilacqua et al, 2022; Matheny et al, 2021; Van Treeck \& Parker, 2018; Van Treeck et al, 2018). Stress granules (SGs) are particularly well-studied granules that form when cellular stress signals mediated by eIF2 $\alpha$ kinase activation (Kedersha et al, 1999) cause individual mRNPs to arrest in translation and condense into multi-mRNP assemblies (Ivanov et al, 2019; Kedersha \& Anderson, 2007; Youn et al, 2019). Mutations in mRNP granule proteins, including TDP-43, FUS, Ataxin-2, hnRNPA1, hnRNPA2B1, EWSR1, have been associated with ALS and/or other forms of neurodegenerative disease (Cirulli et al, 2015; Couthouis et al, 2012; Elden et al, 2010; Ginsberg et al, 1998; Kim et al, 2013; Liu et al, 2017; Taylor et al, 2016; Wolozin \& Ivanov, 2019). For this reason, and because TDP-43 and other stress-granule protein aggregates are components of protein inclusions found in ALS and Frontotemporal dementia (FTD), the regulation and cellular functions of stress granules have been topics of considerable fundamental and clinical interest (Cao et al, 2020; Li et al, 2013; Mallucci et al, 2020; Protter \& Parker, 2016; Wang et al, 2020; Wheeler et al, 2016; Wolozin \& Ivanov, 2019).

The cast of intermolecular interactions required for mRNP-granule assembly and the precise sequence with which they occur are not yet elucidated (Khong \& Parker, 2020; Van Treeck \& Parker, 2018). However, many studies show that intrinsically disordered regions (IDRs) found on mRNP-granule proteins contribute substantially to RNP granule assembly (Andrusiak et al, 2019; Ash et al, 2021; Calabretta \& Richard, 2015; Decker et al, 2007; Gilks et al, 2004; Järvelin et al, 2016; Kim et al, 2021; Yang et al, 2020). In biochemical experiments, such IDRs show the ability to phase separate into liquid-like assemblies (Babinchak \& Surewicz, 2020; Han et al, 2012; Hyman et al, 2014; Kato et al, 2012; Lin et al, 2017; Murray et al, 2017; Murthy et al, 2019; Shin \& Brangwynne, 2017; Strome \& Wood, 1982; Toretsky \& Wright, 2014; Yang et al., 2020) The accessibility or activities of IDRs can be tightly regulated by posttranslational modifications, allowing rapid physiological and spatial control over granule 
assembly and disassembly (Ash et al., 2021; Bah \& Forman-Kay, 2016; Bah et al, 2015; Berlow et al, 2015; Hofweber \& Dormann, 2019; Kwon et al, 2013; Rayman et al, 2018; Saito et al, 2019; Yang et al., 2020).

An important observation is that most IDRs also have the ability to transition from liquid-like states into solid, beta-sheet rich, amyloid-fibrils in vitro, particularly at high concentrations achieved in the liquid-phase (Alberti et al, 2019; Li et al., 2013; Murray et al., 2017; Patel et al, 2015; Ramaswami et al, 2013). This, and studies showing that inhibitors of eIF2 $\alpha$ kinase or downstream events including SG formation can be protective in animal models of neurodegenerative disease (Chou et al, 2017; Halliday et al, 2017; Sidrauski et al, 2015; Wong et al, 2018; Zyryanova et al, 2021) have led to a conceptual framework in which: (a) mRNP granules provide a microenvironment where pathogenic protein seeds can form and grow (Bakthavachalu et al, 2018; Mandrioli et al, 2020; Patel et al., 2015); (b) increased misfoldedprotein loads result in inclusion formation, chronic stress signalling and reduced protein translation (Hetz et al, 2020; Preissler \& Ron, 2019); (c) increased demand on protein handling systems results in multiple cellular defects, notably in the functions of membrane-less organelles (Alberti et al, 2017; Azkanaz et al, 2019; Jiang et al, 2020; Latonen, 2019; Schuller et al, 2021). In particular, aberrant SG formation also results in nuclear transport defects which may contribute to cell death and toxicity (Hochberg-Laufer et al, 2019; Zhang et al, 2018).

Particularly strong support for the role of RNP granule formation in promoting disease comes from studies of Ataxin-2. Loss of Ataxin-2 is cytoprotective in yeast TDP-43 and Drosophila TDP-43 or C9ORF72 or Tau models of cytotoxicity (Bakthavachalu et al., 2018; Becker et al, 2017; Elden et al., 2010; Huelsmeier et al, 2021; Kim et al, 2014; Lee et al, 2016; Shulman \& Feany, 2003). In mouse models for SCA2 or ALS, either genetic loss of ATXN2 or delivery of antisense oligonucleotides (ASOs) targeting ATXN2 in the central nervous system, reduced aggregation of TDP-43, increased animal survival and improved motor function (Becker et al., 2017; Scoles et al, 2017). These observations have led to ASOs against human ATXN2 being developed and approved for clinical trials (Biogen, 2021).

Given Ataxin-2's therapeutic significance and multiple roles in biology, it is particularly important to determine which molecular activities of the protein are relevant to disease and to its various biological functions (Kim et al, 2020). Across species, Ataxin-2 has three conserved regions: a Like-Sm (LSm) domain, an LSm-associated domain (LSm-AD) and a PAM2 motif, 
120 which is flanked by extended intrinsically disordered regions (IDRs) (Boeynaems et al, 2021).

121 Detailed work in Drosophila has shown that a c-terminal IDR of Atx2 is selectively required

122 for mRNP assembly into granules (Bakthavachalu et al., 2018). Parallel experiments showing

123 that the IDR is also required for cytotoxicity in Drosophila FUS, C9ORF72 and Huntington's

124 disease models suggest RNP-granule formation to be a significant mechanism by which Atx2

125 promotes neurodegeneration (Bakthavachalu et al., 2018; Huelsmeier et al., 2021). A recent

126 discovery that the Atx2-LSm domain antagonizes IDR-function has led to a model in which

127 the Atx2 cIDR: (a) does not support mRNP assembly when Atx2 is associated with actively

128 translating mRNAs through Atx2-LSm domain interactions; (b) becomes accessible and active

129 in mediating mRNP assembly when LSm-domain interactions break and mRNA translation

130 stalls (Boeynaems et al., 2021; Singh et al, 2021).

132 We now present a series of experiments further elaborating mechanisms by Ataxin-2 functions

133 in mRNA translation and mRNP assembly. These show that the PAM2 motif of Ataxin-2 and

134 its interactions with PABP are not essential for granule assembly but are required to efficiently

135 recruit Atx2-target mRNAs and specific protein components into Ataxin-2 granules. When

136 taken together with other findings (Boeynaems et al., 2021; Kim et al., 2014; Satterfield \&

137 Pallanck, 2006; Singh et al., 2021), our observations indicate that PAM2 binding to PABP on

138 the polyA tail of mRNAs helps specify the composition of Ataxin-2 granules. We propose an

139 early role for PAM2:PABP interactions working in coordination with the LSm domain to 140 support mRNA translation and thereby oppose the mRNP formation (Boeynaems et al., 2021);

141 as well as a later role in escorting translationally-stalled PAM2:PABP linked mRNAs into

142 mRNP granules. In vivo experiments analysing motor decline in transgenic Drosophila indicate

143 that the PAM2:PABP interactions also support the progression of the neurodegenerative

144 process. We provide new evidence for fresh insight into the enigmatic role of mRNP assembly

145 in neurodegeneration.

\section{RESULTS:}

The structured PAM2 domain of Atx2 is necessary for the correct mRNA and protein content of Atx2 granules.

152 A recent eLife publication used Targets of RNA-Binding Proteins Identified by Editing 153 (TRIBE) technology to identify mRNAs associated with Atx2 in the Drosophila adult brain 
154 (Singh et al., 2021). In vivo, the ability of an Atx2-fusion with ADARcd (the catalytic domain 155 of an RNA-editing enzyme, ADAR), to edit a group of 256 target mRNAs was found to be 156 dependent on the presence of the Atx2-cIDR, previously shown to be necessary for the 157 formation of neuronal mRNP granules in vivo. In contrast, Atx2-ADARcd mutants lacking the 158 LSm domain, both edited Atx2 TRIBE target RNAs and formed mRNP granules in cultured 159 Drosophila S2 cells more efficiently than the wild-type. Thus, Atx2-ADARcd editing of target 160 mRNAs occurs in and is reflective of mRNP granule assembly. While demonstrating a role for 161 LSm-domain interactions in antagonizing cIDR mediated granule assembly, these observations 162 did not address mechanisms by which Atx2 target mRNAs are selected, or whether and how 163 Atx2 played any role in determining the composition of RNP granules. New experiments 164 presented here address these outstanding questions.

166 Previous TRIBE analyses showed that LSm and LSm-AD regions have no major role in the recognition or selection of the Atx2-target mRNAs (Singh et al., 2021). We therefore tested whether the third conserved region of Ataxin-2, a PAM2 motif known to associate with PABP (polyA binding protein), played any role in this process (Jiménez-López \& Guzmán, 2014; Kaehler et al, 2012).

172 We used Gal80 $0^{\text {ts }}$-controlled elav-Gal4 to express Atx2 $\triangle$ PAM2-ADARcd (deleted for the 173 PAM2 motif) in brains of adult Drosophila for 5 days and used RNA-Seq to identify edited RNAs in polyA selected brain mRNA and compare it with Atx2-ADARcd using procedures described earlier (Figure 1A) (McMahon et al, 2016). ADAR-edits, which converts Adenosine to Inosine on RNAs, are identified as A to G changes in TRIBE analyses. Each sample was sequenced to obtain 20 million reads (Supplementary table 1). The edits were only considered from the regions of the transcriptome that contained at least 20 reads. Genes with edits identified at a threshold above $15 \%$ in two biological replicates were considered as highconfidence true targets. We compared edit frequency and edited-gene identity in the brains of flies expressing Atx2 $\mathrm{PAAM} 2-\mathrm{ADAR} c \mathrm{w}$ with those in brains expressing Atx2-ADARcd.

183 In contrast to Atx-2 forms lacking LSm or LSm-AD domains (Singh et al., 2021), 184 Atx2 $\triangle$ PAM2-ADARcd edited significantly fewer RNA targets than wild-type Atx2-ADARcd 185 (108 genes and 165 edits vs 256 genes and 317 edits, Figure 1B, C and Supplementary table 186 2). More striking, the cohort of mRNAs edited by the $\triangle P A M 2$ mutant form differed extensively 187 from the largely overlapping cohorts edited by either wild-type forms of Atx2 (Figure 1C). Of 
the 108 genes edited by Atx2 $\triangle$ PAM2-ADARcd, 36 were also targets of Atx2-ADARcd, the remaining 72 were unique. (Figure 1C, D and Supplementary table 2). 50 edit sites were common between the Atx2 $\triangle \mathrm{PAM} 2$ and Atx2WT targets. Those sites were edited with much lower efficiency in Atx2 $\triangle \mathrm{PAM} 2$ as compared to Atx2WT (Figure 1E).

The location of edits made by Atx2 $\triangle$ PAM2-ADARcd also differed dramatically as to where they occurred relative to the coding sequences of the target mRNAs (Figure 1F). While edits made by wild-type and $\triangle \mathrm{LSm}$ forms of Atx2-ADARcd were greatly enriched in the 3'UTR of the mRNAs, Atx2 $\triangle$ PAM2 targets were edited indiscriminately all along the mRNA length (Figure 1F).

Taken together, these data identify the PAM2 motif as necessary for Atx 2 engagement with its correct mRNA targets. The PAM2 motif interacts with PABP, which binds polyA tracts at the 3' end of mRNAs (Deo et al, 1999). Therefore, the data point to a role for the structured PAM2:PABP interaction in guiding the association of Atx2 with mRNAs and for subsequent inclusion of these mRNAs in Atx2-containing granules.

If Atx2-ADARcd edits of target mRNAs occur predominantly in the mRNP granules (Singh et $a l ., 2021)$, then the ability of Atx2 $\triangle$ PAM2-ADARcd to edit some target mRNAs would suggest that the PAM2 motif is not essential for mRNP granule formation per se. To examine this, we expressed wild-type and $\triangle \mathrm{PAM} 2$ mutant forms of GFP-tagged Atx2 under control of the native genomic promoter in Drosophila S2R+ cells. Atx2 overexpression in S2 cells induced the formation of mRNP granules closely related to SGs, containing endogenous Atx2 and various SG proteins as previously reported (Figure 2A) (Bakthavachalu et al., 2018; Singh et al., 2021). Similar expression of Atx2 $\triangle$ PAM2-GFP also induced granule formation. However, these granules were compositionally distinct from those induced by Atx2-GFP. While they clearly contained some SG markers present on Atx2-granules, e.g., Me31B and Rox8 (Drosophila homologs of DDX6 and TIA1), they did not contain others such as PABP, Caprin and dFMRP (Figure 2B).

218 RNP-granules induced by expression of wild-type, LSm and PAM2 deficient forms of Atx2-

219 GFP required the presence of the c-terminal IDR (Figure 2C). Thus, while largely dispensable 220 for efficient mRNP assembly, the PAM2 domain plays a significant role in determining both mRNA and protein components of mRNP granules. One possibility is that the PAM2 motif 
A.

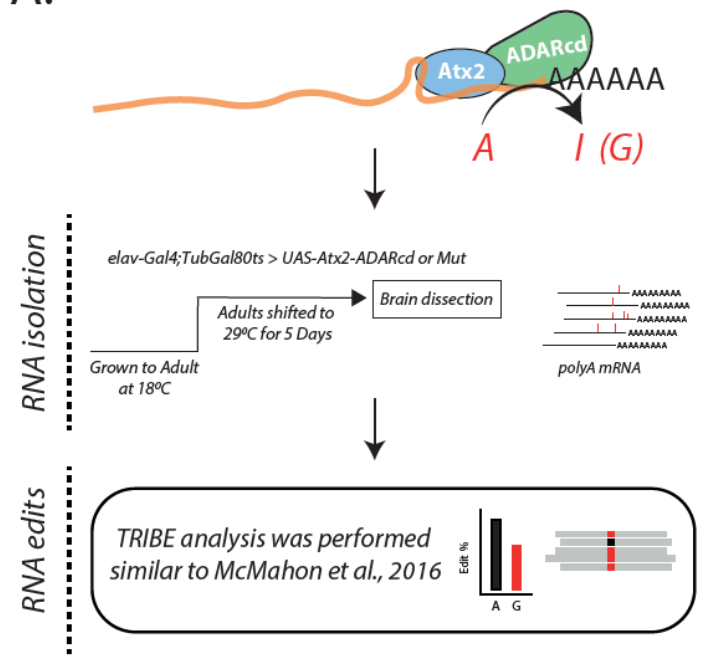

E.

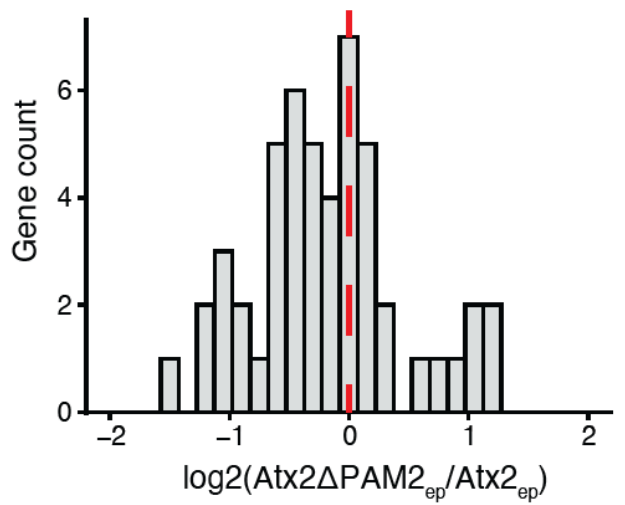

B.

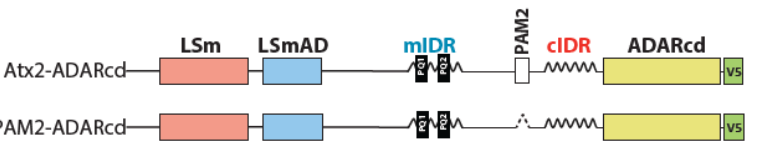

C.

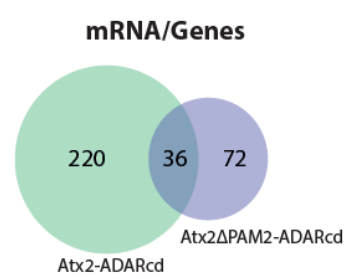

D.

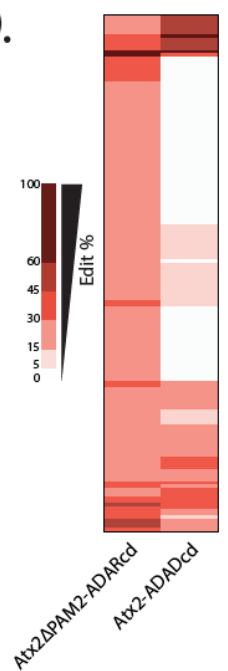

$\mathrm{F}$.
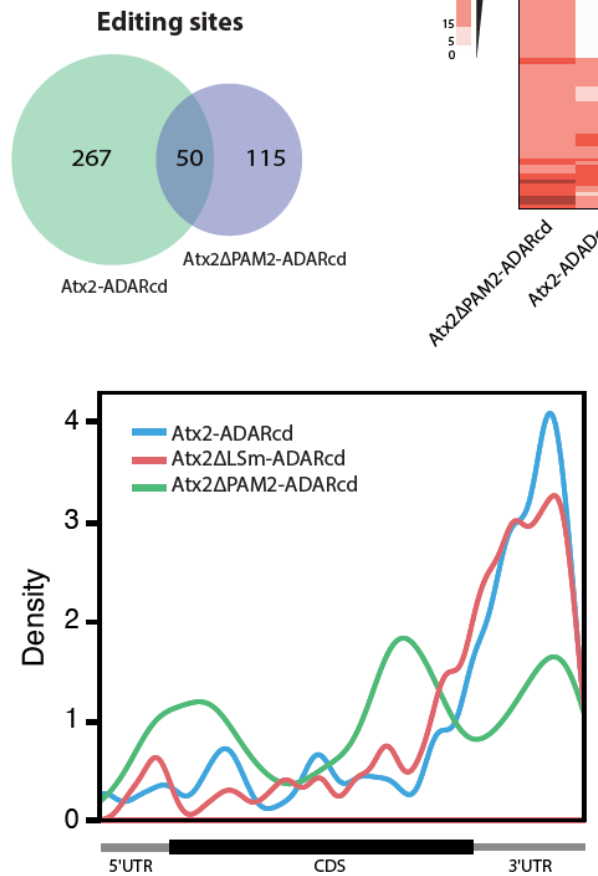

Figure 1: The PAM2 domain facilitates the selection of Atx2 RNA targets. (A). Flowchart depicting the TRIBE analyses pipeline. Atx2 $\triangle$ PAM2-ADARcd was expressed in adult Drosophila brains. Total brain RNA was isolated and RNA edits were identified and compared to Atx2-ADARcd, similar to Singh et al 2021. (B) Domain map of Atx2-ADARcd constructs used for TRIBE analysis. (C) Comparisons of genes and edits identified by TRIBE between Atx2-ADARcd and Atx2 $\triangle$ PAM2-ADARcd targets. (D) Most Atx2 $\triangle \mathrm{PAM} 2$ targets identified by TRIBE are unique and not edited in Atx2WT, suggesting that these new targets bound by Atx $2 \triangle \mathrm{PAM} 2$ are not native Ataxin-2 granule targets. (E) Comparisons of the editing efficiency ratio of common edits between Atx2WT vs Atx2 $\mathrm{P} A M 2$ show a much lower editing efficiency in Atx2 $\triangle \mathrm{PAM} 2$ compared to Atx2WT. (F) PAM2 deletion results in loss of 3'UTR specificity seen in Atx2WT and LSm deletion TRIBE target mRNAs. Atx2WT and Atx2 $\Delta$ LSm-ADARcd data are extracted from (Singh et al 2021). 
A.

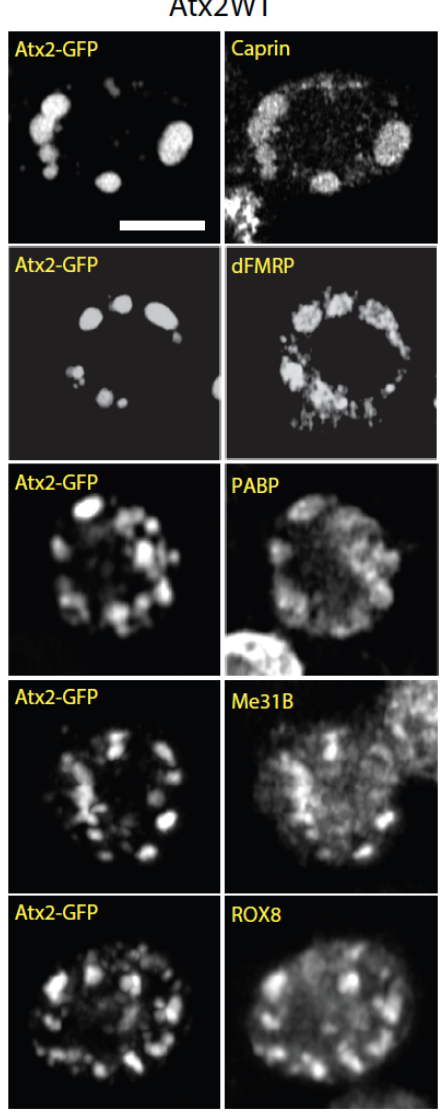

B.

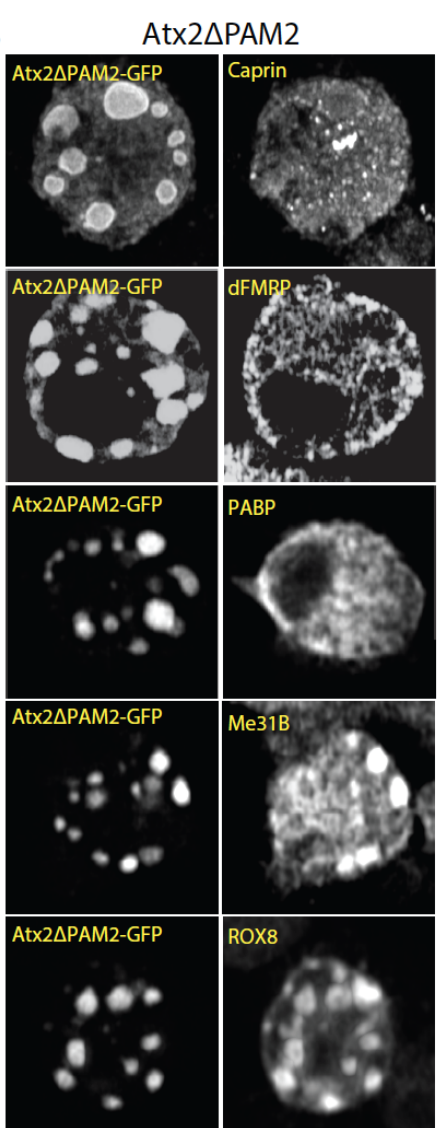

C.

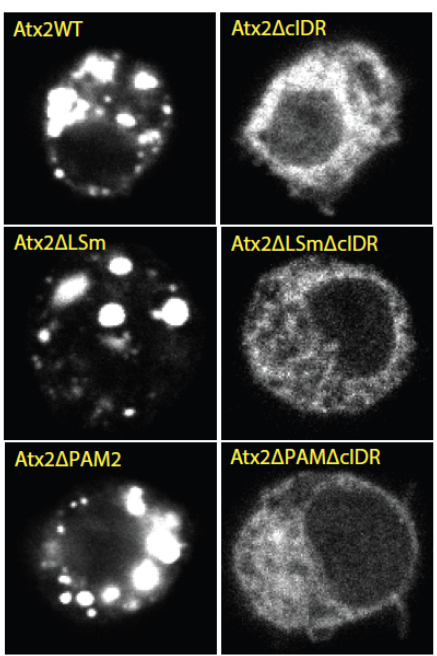

Figure 2: Presence of the PAM2 domain affects the protein composition of Atx2-GFP granules in S2 cells. (A) Over-expression of Atx2-GFP in unstressed Drosophila S2 cells induces the formation of Atx2GFP granules to which various SG markers co-localize. (B) Deletion of the PAM2 affects the Atx2-GFP granule composition. Over-expression of Atx2 $\triangle \mathrm{PAM} 2-\mathrm{GFP}$ in S2 cells still induces the formation of granules, but some SG markers fail to co-localize in these, notably dFMR, Caprin and PABP. (C) Atx2GFP granule formation in S2 cells relies primarily on the cIDR. Deletion of the cIDR in Atx2WT, Atx2 $\triangle \mathrm{PAM} 2$ and Atx2 $\triangle \mathrm{LSm}$, removes their ability to form granules upon overexpression. See Supplemental Figure 1, A-B, for quantification. The scale bar in (A) applies to (B) and (C). Scale bar $=5$ $\mu \mathrm{m}$,

\section{PAM2:PABP interactions are sufficient for Atx2 to associate with stress granules}

249 We wanted to directly confirm Ataxin-2 PAM2 motif interactions with PABP and analyse their

250 relevance to RNP granule assembly. For this, we generated constructs encoding SNAP-epitope

251 tagged variants of Atx2. These were radically truncated forms of Drosophila and human 252 Ataxin-2 proteins containing only the LSm, LSm-AD and PAM2 elements and lacking all 253 unstructured regions of the protein. The structured elements are connected via flexible linkers 254 (Figure 3A). These "Mini-Ataxin-2" constructs and their domain-deleted forms allowed us to separate functions of the structured regions of Ataxin-2 from those of the remaining extended 
disordered regions. A similar approach has been previously shown for MeCP2 (Tillotson et al, 2017). We identified key residues involved in Drosophila Atx2-PAM2:PABP interactions based on a previously solved crystal structure of a strongly conserved mammalian PAM2:PABPC1-MLLE domain complex (Kozlov et al, 2010; Xie et al, 2014) (Figure 3B). Residues leucine 914 and phenylalanine 921 (L914 and F921) in the human ATXN2-PAM2 motif are predicted to contact the PABPC-MLLE domain and of these, F921 has been shown to be required for the PABPC-ATXN2 interaction (Inagaki et al, 2020). These residues (L859 and F866, respectively) are perfectly conserved in fly Atx2 (Supplementary Figure 3). In order to allow more precise disruption of PAM2:PABP interactions and avoid potential unknown secondary effects of larger PAM2 motif deletions, we additionally generated mini Ataxin-2 constructs where these PABP-contacting residues were singly or doubly altered to alanine. We used these constructs for co-immunoprecipitation (Figure 3) and co-localization (Figure 4) analyses to examine the contribution of PAM2:PABP/PABPC1 interactions in RNP-granule formation.

270

271 We expressed SNAP-tagged wild-type and mutant forms of mammalian and Drosophila mini-

272 Ataxin-2 in HEK293T and S2 cells, respectively. We tested which Ataxin-2 domains were 273 required for SNAP substrate beads to successfully immunoprecipitate Ataxin-2 complexes 274 containing PABPC1/PABP from cell lysates (Figure 3C-E). Both LSM12 and PABPC1 275 proteins were co-immunoprecipitated with mammalian mini-ATXN2. However, PABPC1 co276 immunoprecipitation was selectively lost when the PAM2 domain was deleted or if predicted 277 PABP-contact residues in the PAM2 domain were mutated (Figure 3C). Similar to the human 278 homolog, fly mini-Atx2-SNAP also required the presence of its PAM2 motif with both 279 predicted contact residues intact for immunoprecipitation of PABP from Drosophila S2 cell 280 lysates (Figure 3D). Taken together with previous observations, these data support a potential 281 sequence of molecular events. In unstressed cells, PAM2 domain interaction with PABP help 282 position Ataxin-2 at the 3'-end of mRNAs while LSM-domain association with LSM12 283 stimulate translation of these mRNAs; under stress conditions (or Ataxin-2 overexpression), 284 translation is arrested and the cIDR domain freed to mediate interactions that facilitate the formation of condensed RNP granules (see Discussion) 
A.

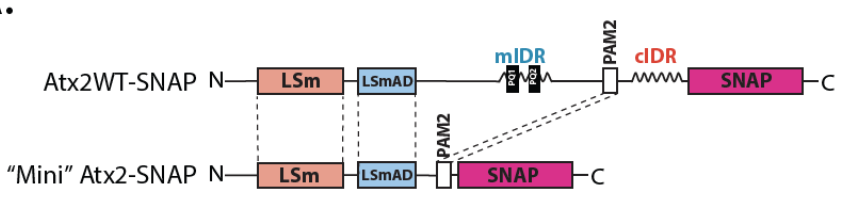

B.

\section{Conserved PAM2-PABP interaction in: Human Fruit Fly}
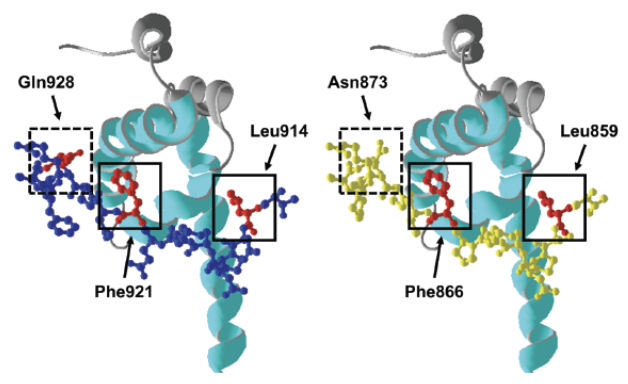

D.

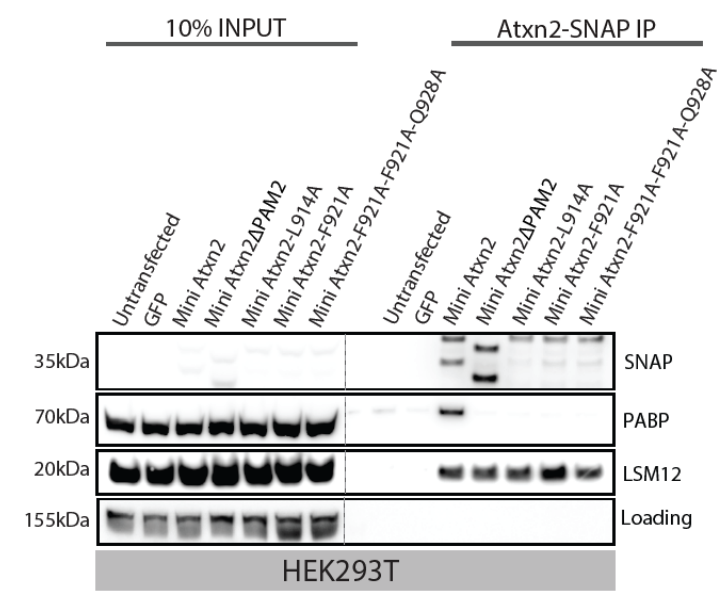

Domain deleted "Mini" Atx2-SNAP

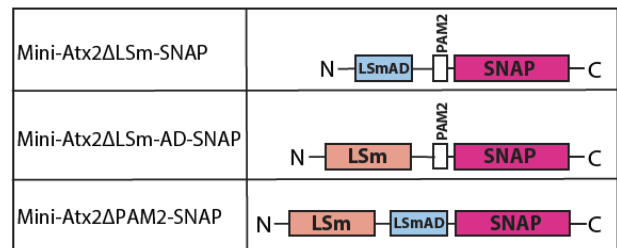

C. $10 \%$ INPUT Atxn2-SNAPIP

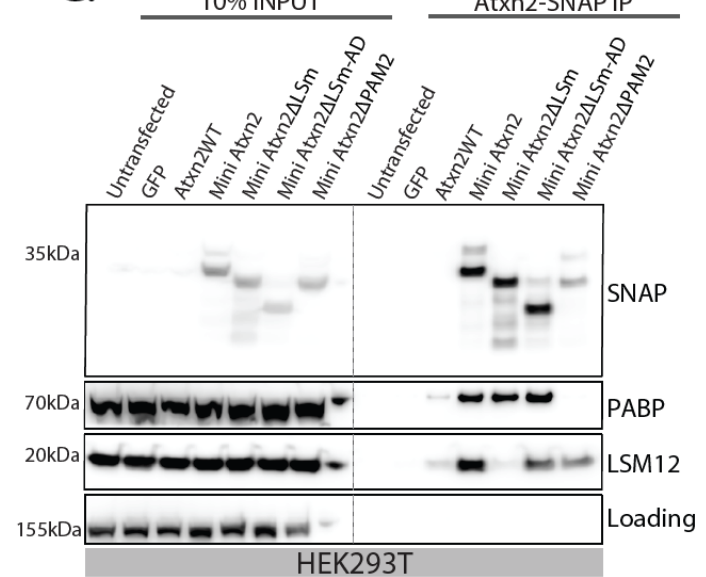

E.

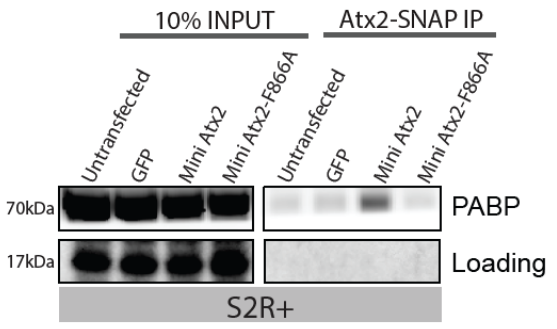

Figure 3: A minimized Ataxin-2 construct containing only the known structured domains maintains the ability to interact with PABP and LSM12. (A) Schematic of SNAP-tagged full length, minimal, and minimal domain-deleted constructs of fly Atx2 used to isolate the function of the structured domains of the protein without interference from IDR-mediated interactions. Human and Drosophila Ataxin-2 LSm, LSm$\mathrm{AD}$ and PAM2 domains show high amino acid sequence similarity (Clustal $\Omega$ ) of $70 \%, 82 \%$ and $87 \%$ respectively. This suggests conserved and specific function of these structured domains. (B) Structural model of the PABP MLLE domain (ribbon) showing the near-perfect structural similarity of the human ATXN2 PAM2 domain (blue, uniprot ID: Q99700) with the Drosophila Atx2 PAM2 domain (yellow, uniprot ID: Q8SWR8). The key interacting residues are highlighted in red. (C) Human minimized ATXN2 SNAP IP-WB from HEK293T cells probing for PABP and LSM12 showing the effects of different domain deletions. The PAM2 domain is necessary and sufficient for the ATXN2-PABP interaction, while the LSm domain is necessary and sufficient for the ATXN2-LSM12 interaction. (D) Point-mutations targeting key interacting residues of the PAM2 domain were predicted to replicate the 
effect of a full PAM2 deletion in the minimized Atx2 construct. Human minimized ATXN2-SNAP IP WB from HEK293T cells showing that mutating either of the key hydrophobic residues L914 or F921 in the PAM2 domain is sufficient to prevent its interaction with PABP. The interaction with LSM12 is unaffected by the point mutations. (E) Drosophila minimized Atx2-SNAP IP-WB from S2 cells. An analogous PAM2 domain point mutation on F866 blocks the Atx2-PABP interaction.

Single mRNAs usually associate with multiple PABP molecules because their polyA tails are considerably longer than the $\sim 24$ bases required for PABP binding (Mangus et al, 2003). Thus, in cells expressing endogenous and mini Ataxin-2, mRNAs could have both forms associated with their polyA tails. In response to stress, mini Ataxin- 2 would be expected to move into SGs whose formation is facilitated by IDRs on endogenous Ataxin-2 associated with the common target RNAs. We examined this possibility in cells before and after oxidative stress.

313 Drosophila and human mini-Ataxin-2-SNAP, expressed in fly S2 or human U2OS cells respectively, were diffusely localized in the cytoplasm and neither induced formation of Ataxin-2 foci. However, when cells were exposed to sodium arsenite to induce SG formation, SNAP-tagged mini-Atx2 (Figure 4A) and mini- ATXN2 (Figure 4H) were robustly recruited to stress granules. Thus, association of Ataxin- 2 with mRNP-granule components may be achieved by structured domain interactions alone, independently of IDRs required for mRNP assembly into granules.

Further experiments examined which of the LSm, LSm-AD and/or PAM2 domains were necessary for mini-Ataxin-2 to associate with stress granules. Mammalian and Drosophila mini-Ataxin-2 forms missing the LSm or LSm-AD domains could still be found in stress granules (Figure 4B-C and I-J). In contrast, mutants lacking the PAM2 domain remained cytoplasmic after stress in both S2 (Figure 4D) and U2OS cells (Figure 4K). Notably, point mutations in the Ataxin-2-PAM2 domain that specifically disrupt PAM2:PABP interaction similarly prevent localization to stress granules (Figure 4E-G and L-N). Thus, interactions between Ataxin-2's PAM2 domain and PABP appear important for the presence of Ataxin-2 in native mRNP granules, whose assembly is driven by the distinct (IDR) region of the protein

330 (Figure 2C). The ability of otherwise full-length Ataxin-2 lacking PAM2 to form compositionally distinct $\mathrm{mRNP}$ assemblies (Figure $2 \mathrm{~B}$ ) suggests that PAM2:PABP binding also serves to limit non-physiological interactions by Ataxin-2 (See Discussion). 
bioRxiv preprint doi: https://doi org/10.1101/2022.02.15.480566; this version posted February 17, 2022. The copyright holder for this

preprint (which was not certified by peer review) is the author/funder, who has granted bioRxiv a license to display the preprint in perpetuity. It is made available under aCC-BY-NC-ND 4.0 International license.

A.

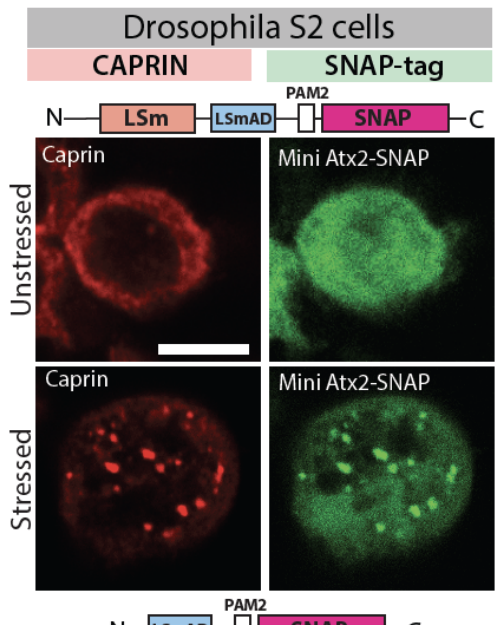

B.

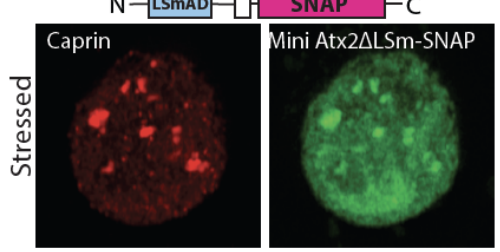

C.

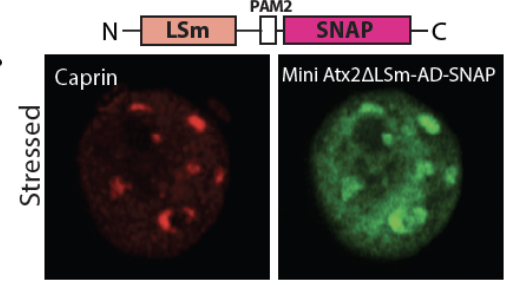

D.

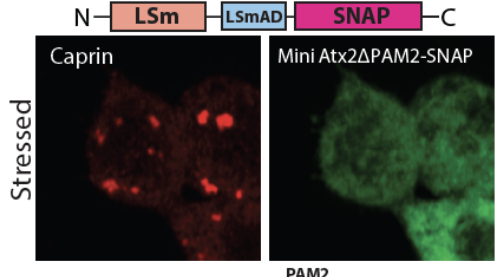

E.
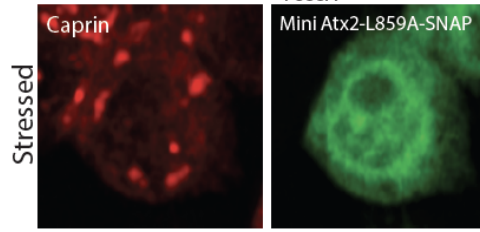

F.
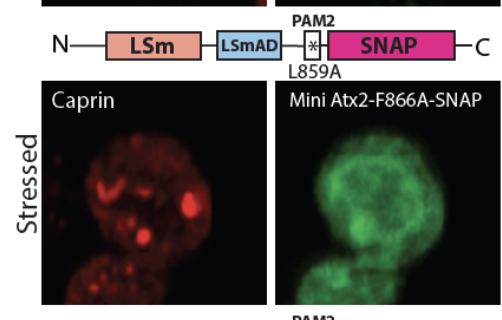

G. $N-L S m L L$ LSTAD
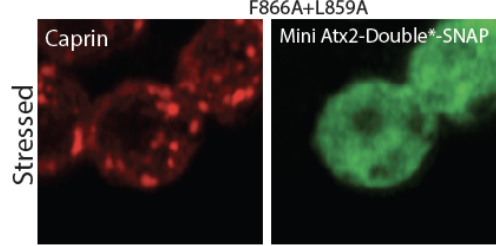

H.
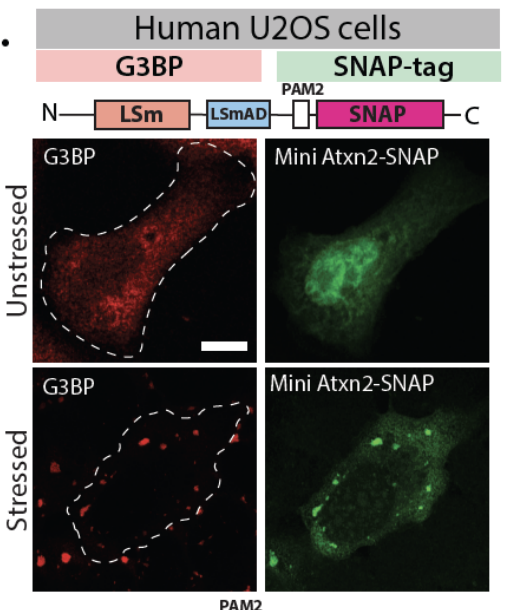

I.
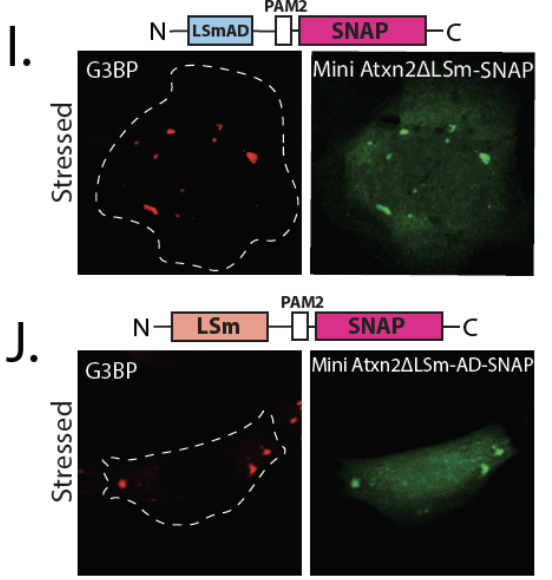

K. $\mathrm{N}-L \mathrm{LS}-L$ LSMAD SNAP $-\mathrm{C}$
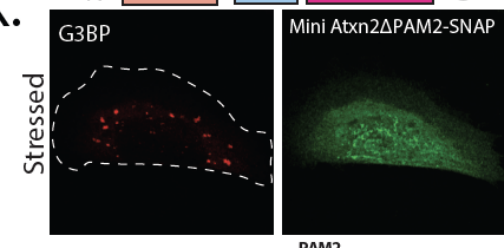

L.
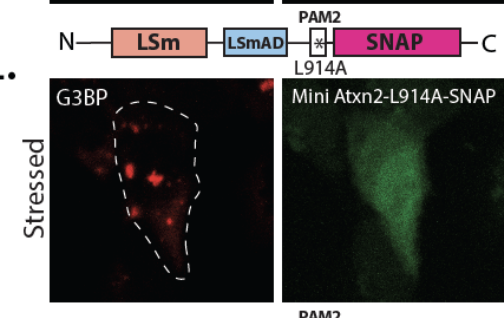

M. $\mathrm{N}-L S m$

PAM2

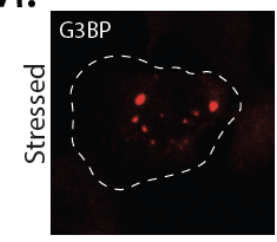

Mini Atrn2-Fon

N. N-LSm LSmAD * -

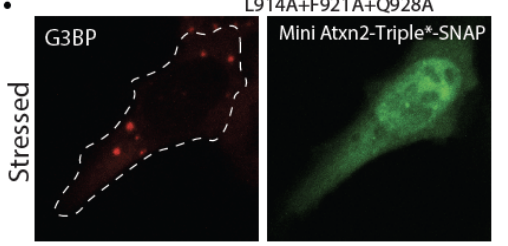


Figure 4: The structured PAM2 domain is necessary and sufficient for Ataxin-2 recruitment to Stress Granules in both Drosophila and human cells. (A) In Drosophila S2 cells mini-Atx2-SNAP (green) is recruited to SGs induced by arsenite. (B) Deletion of LSm or (C) LSm-AD domains has no significant effect in the arsenite-induced SG recruitment. (D) The presence of PAM2 domain, and specifically its key PABP-interacting amino acids (E-G), is necessary for Atx2 recruitment to SGs. Caprin (red) was used as SG granule marker, scale bar $=5 \mu \mathrm{m}$, (H) Human mini-ATXN2-SNAP (green) is recruited to arseniteinduced SGs in human U2OS cells. (I) Deletion of LSm or (J) LSm-AD domains has no effect on the arsenite-induced SG recruitment of ATXN2. (K) Deletion of the PAM2 domain, and specifically its PABP-interacting amino acids (L-N), are necessary for ATXN2 recruitment to SGs. G3BP1 (red) was used as SG marker; scale bar $=10 \mu \mathrm{m}$. Schematics above images indicate the domain deletions or amino acid mutations that were made in the different Ataxin-2 constructs. See Supplemental Figure 1C for

The IDR and PAM2 domains promote and the LSm domain inhibits cytotoxicity in Drosophila neurodegeneration models.

Three different Ataxin-2 domain deletions tested showed three distinct effects on mRNP granule assembly in S2 cells. IDR domain deletions prevent Ataxin-2 granule formation. LSmdomain deletion enhances the formation of Ataxin-2 granules. PAM2 domain deletions result in the formation of unusual mRNP assemblies (Bakthavachalu et al., 2018; Singh et al., 2021) (Figure 2B/C). Prior observations showing that Atx2 IDR deletions suppress cytotoxicity in Drosophila models for neurodegeneration indicate that mRNP granules support events that lead to degenerative disease (Bakthavachalu et al., 2018; Becker et al., 2017; Huelsmeier et al., 2021; Scoles et al., 2017). If true, the expression of Atx $2 \Delta \mathrm{LSm}$, which enhances granule assembly, would promote or potentially accelerate the degeneration, while the expression of Atx $2 \Delta$ cIDR would not. The expression of Atx $2 \Delta$ PAM2 would be expected to support mRNP assemblies of different compositions from the ones containing wild-type or $\Delta \mathrm{LSm}$ forms of Atx2. The effects on degeneration for this condition would be hard to predict.

364 To examine how the different Atx-2 domain deletions affect nervous system integrity and 365 function over time, we combined a Gal4-responsive UAS-Atx2 transgene with elav-Gal4 and $T u b G a l 80^{t s}$. This allows us to use a temperature shift from $18^{\circ} \mathrm{C}$ to $30^{\circ} \mathrm{C}$ to induce $U A S$-Atx2 transgene expression, specifically in the brains of adult flies (Figure 5A). We then analysed the rate at which flies climbed the walls of a glass cylinder, a surrogate measure of motor ability, 
370 comparable levels of climbing ability on day 1. Interesting variations were identified on day

371 15. The 15-day old flies expressing Atx2WT or Atx2 2 LSm showed a strong decline in

372 climbing ability. In contrast, Atx2 $\Delta$ cIDR flies showed a minimal decline (Figure 5B). These

373 observations were in line with the effects of these Atx 2 types on granule formation. Strikingly,

374 flies expressing the Atx2 $\triangle \mathrm{PAM}$ variant, which formed compositionally distinct granules in S2

375 cells, showed no significant decline in climbing ability, suggesting that Atx2's ability to

376 promote progressive decline of neural function depends less on Atx2 granule formation and

377 aggregation, but a bit more on its sequestration of critical translation factors such as PABP (and

378 associated RNAs.(Figure 5B). These observations support and extend prior work showing that

379 heterologous overexpression of full-length, but not PAM2-domain deleted forms of

380 mammalian ATXN2 enhances mammalian TDP-43-induced degeneration of the Drosophila

381 compound eye (Kim et al., 2014). They are also consistent with work in mice showing that

382 PABPC1 sequestration in inclusions correlates strongly with the progression of

383 neurodegeneration (Damrath et al, 2012).

384

385 The conclusion, that PAM2 mediated interactions were required for progressive cytotoxicity,

386 is further supported by a parallel series of experiments in which we used mef2-Gal4 in place

387 of elav-Gal4, to target UAS-Atx2 transgene expression to Drosophila adult muscles (Figure

388 5C). Micro-computed tomography (micro-CT) scanning to visualize the integrity of flight

389 muscle fibers in whole-mount preparations (see Methods) revealed degeneration of muscles

390 expressing wild-type Atx2 in 20-day old flies. While there was more severe degeneration in

391 Atx2 $\Delta$ LSm expressing muscle, muscles similarly expressing Atx2 $\Delta$ cIDR or Atx2 $\triangle \mathrm{PAM}$ forms

392 showed no morphological defects (Figure 5C and Supplementary Figure 4). 
A.

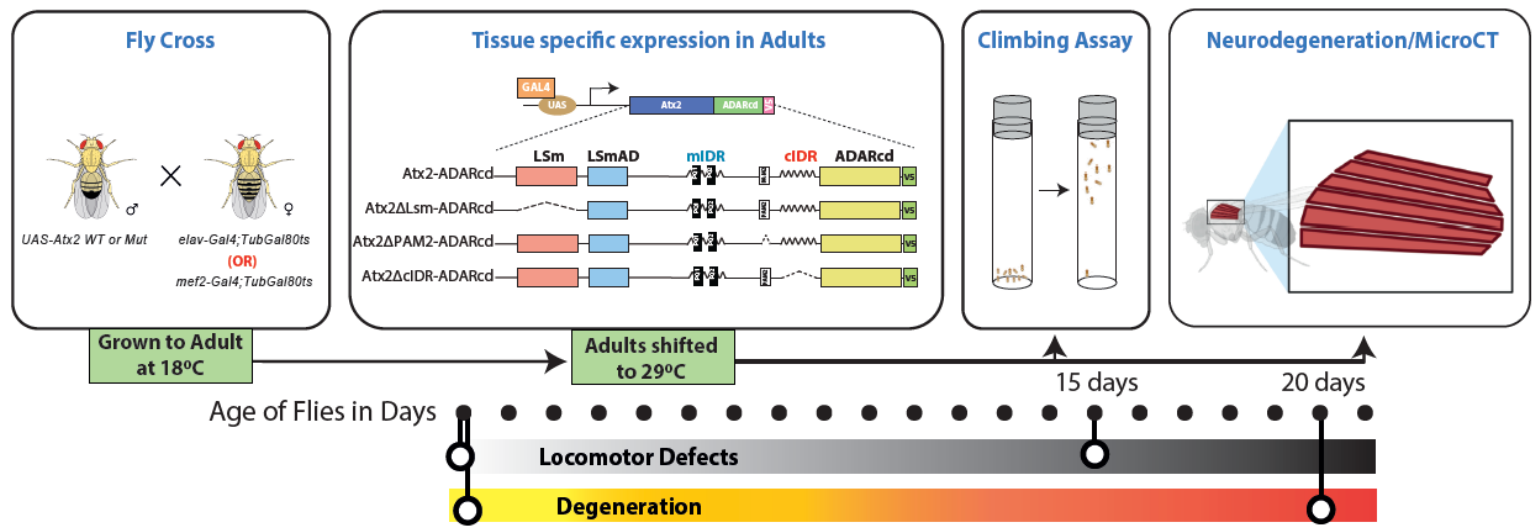

B.
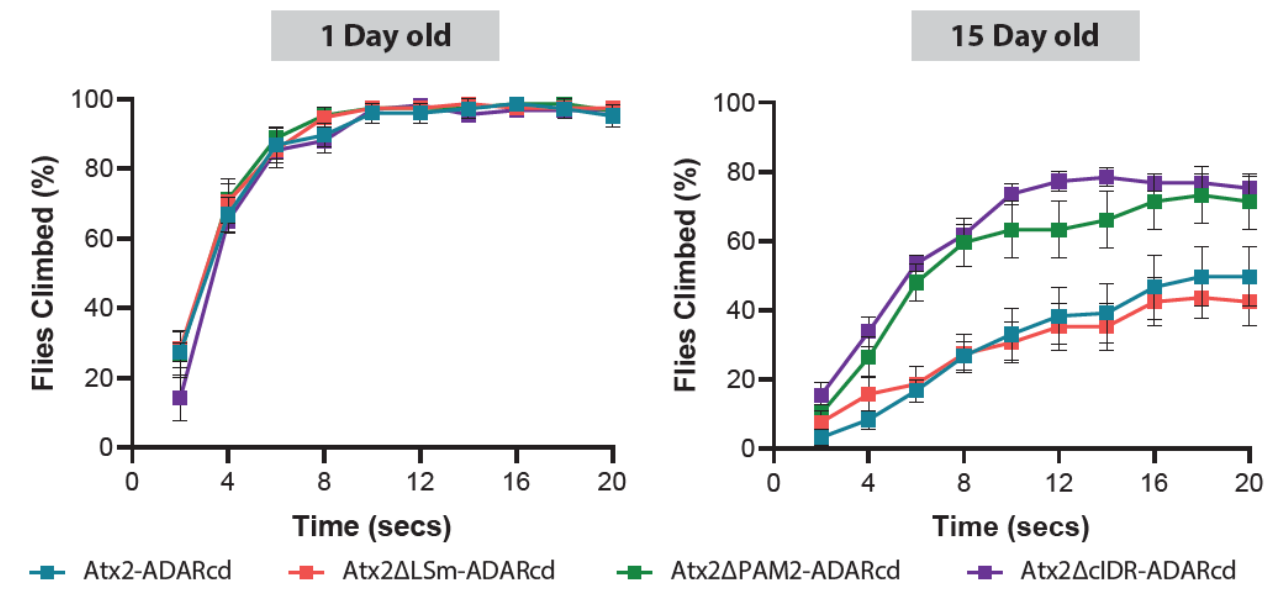

C.
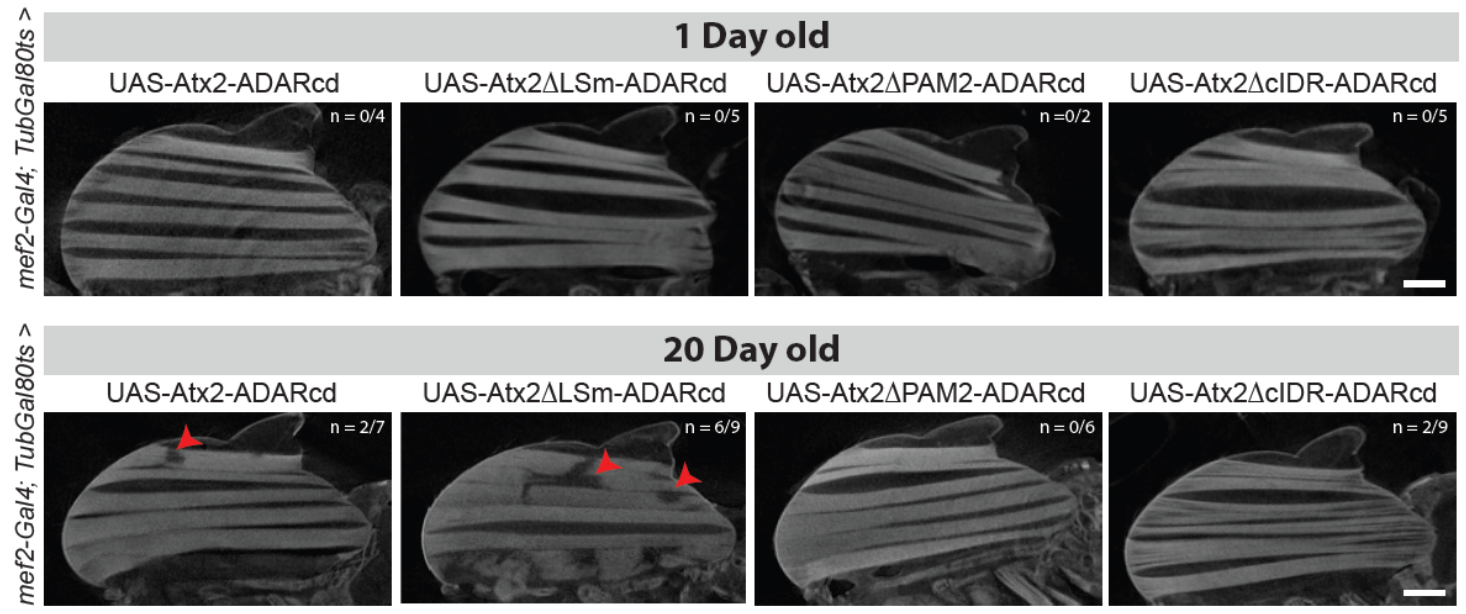

Figure 5: The IDR and PAM2 domains promote and the LSm domain inhibits neurodegeneration

in Drosophila. (A) A schematic of the experimental design is shown. UAS-transgenes were crossed with

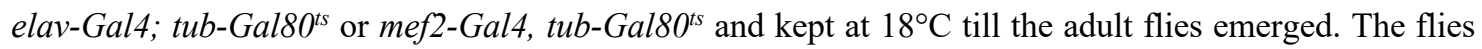
were shifted to $29{ }^{\circ} \mathrm{C}$ for days shown with dots under the experimental design. Fly climbing or indirect flight muscle cytotoxicity was studied. (B) Drosophila climbing behavior assay was performed by driving UAS-transgene (Atx2WT, Atx2 $\Delta \mathrm{cIDR}$, Atx2 $\triangle \mathrm{PAM}$ or Atx2 $\Delta \mathrm{LSm}$ ) with elav-Gal4. A graph was plotted with number of flies ( $\mathrm{Y}$-axis) that crossed the $20 \mathrm{ml}$ mark at a given time (X-axis). (C) Cellular toxicity was measured by driving UAS-transgene (Atx2WT, Atx2 $\Delta \mathrm{cIDR}$, Atx2 $\triangle \mathrm{PAM}$ or Atx $2 \Delta \mathrm{LSm}$ ) with mef2- 


\section{DISCUSSION}

406 The results described above provide three significant lines of insight. First, they support a detailed model for sequential protein-protein interactions through which Ataxin-2 can modulate different translational states of a single mRNA. Second, they show that the Ataxin-2 polypeptide contains distinct activities that promote or protect against neurodegeneration, pointing to the value of developing therapeutics that target specific Ataxin-2 interactions, beyond those that reduce overall levels of the protein. Third, the work identifies a novel molecular mechanism involving the PAM2 domain and PABP that contributes to the assembly of mRNP granules.

\section{Molecular mechanisms of Ataxin-2 function}

416 Some RNA-binding proteins can remain associated with mRNAs across multiple stages: RNA 417 processing, transport, translation, or translational control (Formicola et al., 2019; Gomes \& 418 Shorter, 2019; Hachet \& Ephrussi, 2004; Harlen \& Churchman, 2017; Lin et al, 2015; Maniatis $419 \&$ Reed, 2002). Ataxin-2 may be one such protein. It is a translational activator of the 420 Drosophila period mRNA, a repressor of several miRNA reporters, a facilitator of neuronal mRNP-granule and stress-granule formation as well as a broad stabilizer of Ataxin-2 associated mRNAs (Bakthavachalu et al., 2018; Inagaki et al., 2020; Lim \& Allada, 2013; McCann et al, 2011; Nonhoff et al, 2007; Sudhakaran et al, 2014; Yokoshi et al, 2014; Zhang et al, 2013).

424 While these different functions could represent different modes of engagement with distinct sets of mRNAs, the data are also consistent with another model. Sequential interactions mediated by different protein regions during mRNP modelling allow Ataxin-2 to contribute in multiple ways to translational control to a single mRNA.

429 Previous work has shown that Atx-2 enhances period mRNA translation through a mechanism 430 requiring LSm-domain interactions with a complex of LSM12 and TYF (Twenty Four) proteins 431 associated with the 5' cap of the translating mRNA (Lee et al, 2017; Lim \& Allada, 2013; Zhang 432 et al., 2013). Given considerable supportive evidence for direct binding between the LSm433 domain and LSM12, we postulate that LSm-domain-LSM12 interactions occur in translating 434 polysomes (Satterfield \& Pallanck, 2006) and contribute to increased efficiency of translation. 
bioRxiv preprint doi: https://doi.org/10.1101/2022.02.15.480566; this version posted February 17, 2022. The copyright holder for this preprint (which was not certified by peer review) is the author/funder, who has granted bioRxiv a license to display the preprint in perpetuity. It is made available under aCC-BY-NC-ND 4.0 International license.

435

436

437

438

439

440

441

442

443

444

445

446

447

448

449

450

451

452

453

454

455

456

457

458

459

460

461

462

463

464

465

466

467

This proposal is consistent with the observation that the LSm domain opposes the formation of mRNP granules, which usually contain translationally repressed mRNAs (Singh et al., 2021).

However, the LSm domain must also contribute to LSM12-independent functions, because while LSm-domain deletions from Drosophila Atx2 cause lethality and LSM12 null mutants, while arrhythmic, are viable and fertile (Lee et al., 2017). One possibility is that LSm domains additionally contribute, perhaps indirectly, to interactions with the DEAD-box helicase Me31B/DDX6 in a translational repressor complex (Brandmann et al, 2018; Lee et al., 2017). Thus, we suggest that in the case of actively translating mRNAs, the Atx 2 function is driven by LSm-domain association with LSM12 and translational initiators, and that LSM12 disengages from a translational initiation complex as the mRNA transitions into a repressed state driven by Me31B.

While polyA tails and PABP are known to support translation and the Ataxin-2 PAM2 domain is involved in targeting the protein to polysomes (Satterfield and Pallanck, 2006), existing data do not directly address how Ataxin-2 PAM2 motif interactions contribute to translational activation. One possibility, supported by observations on the period mRNA is that the PAM2domain guides Ataxin-2 to the 3'UTR of its target mRNAs (Lim \& Allada, 2013). Our observation that PABP co-immunoprecipitates with mini-Ataxin2, show that Atx2PAM2:PABP interactions occur independently of and prior to mRNP granule formation. Recent findings that this association antagonizes the Ataxin-2 condensation (Boeynaems et al., 2021) are consistent with a model in which the Atx2-PAM2 motif interacts with PABP in translating mRNAs to support efficient translation driven by the LSm-LSM12 complex. However, in addition to supporting translation, PABP is also known to associate with translational repressors that could drive either mRNA deadenylation and/or storage (Machida et al, 2018; Yoshida et al, 2006). Our data support such a dual role for Ataxin-2 associated with PABP in translational repression. First, when Ataxin-2 target mRNAs are not actively translated, then the mRNP through Me31B/DDX6 and PABP may recruit deadenylases to transition into either a translationally dormant or degradative state (Lee et al., 2017; Machida et al., 2018; Yi et al, 2018; Yoshida et al., 2006). Second, Atx2 associated mRNA may move into mRNP granules whose formation is facilitated by Atx2 IDR-mediated condensation. We postulate that mRNAs in such assemblies are stored in a form that is protected from degradation. While the above model, shown in Figure 6, is consistent with all our data, we 
acknowledge that it needs extensive and rigorous testing in the context of the life cycle of a single Ataxin-2 target mRNA.

\section{Implications for Ataxin-2 as a therapeutic target}

Antisense Oligonucleotide (ASO) based therapeutic strategies that lower levels of Atxn-2 are being developed for the treatment of ALS and spinocerebellar ataxia type 2 (SCA2) (Becker et al., 2017; Scoles et al., 2017). Our experiments provide a much finer grained analysis of activities of Ataxin-2, suggesting that the function of the LSm domain should be spared, and that IDR mediated assembly mechanisms and perhaps PAM2:PABP interactions should be most usefully targeted by therapeutics.

Our previous work showed that Atx2 mutants lacking the cIDR required for Ataxin-2 granule formation in Drosophila neurons and S2 cells, were resistant to neurodegeneration as assessed in Drosophila disease models (Bakthavachalu et al., 2018; Huelsmeier et al., 2021). We further showed that the LSm-domain antagonizes Ataxin-2 granule formation (Singh et al, 2021). Here we advance the latter observation by demonstrating that Ataxin-2 forms lacking the LSm domain may more effectively cause cytotoxicity than the wild-type or IDR-deficient forms (Figure 5C). These observations independently confirm our original conclusions and-provide further support for a model in which the efficiency of mRNP assembly correlates with the speed and severity of neurodegenerative processes in Drosophila.

The importance of the PAM2 domain in promoting degeneration has been previously observed by experiments showing that heterologous expression of a pathogenic form of human Ataxin2 lacking its PAM2 domain, but not the full-length form, suppresses cytotoxicity in Drosophila expressing human TDP-43 (Kim et al., 2014). Our observations that expression of Atx $2 \triangle \mathrm{PAM} 2$ is far less toxic than expression of wild-type Atx2 is consistent with this. In addition, by showing that Atx2 $\triangle \mathrm{PAM} 2$ forms compositionally different Ataxin-2 granules, they highlight the importance of specific granule components, and not granules per se, in neurodegenerative pathologies. Thus, while liquid-liquid transitions mediated by disordered domains could be a shared requirement for the formation of multiple types of mRNP granules, we speculate that each granule type, with distinctive composition, could preferentially support one or other type of proteinopathy (De Graeve \& Besse, 2018; Vogler et al, 2018).

\section{Structured interactions may determine mRNP granule composition.}


Many lines of evidence argue that specific molecular interactions, e.g. mediated by structured domains of the P-body component Edc3 or the stress-granule components G3BP and Caprin, contribute to the mRNP granule formation (Decker et al., 2007; Kedersha et al, 2016). In engineered systems, the condensation of RNA-binding proteins and mRNAs into granules has been clearly shown to depend on both traditional protein-protein interactions and on more promiscuous interactions between intrinsically disordered regions (Protter et al, 2018). Our work now identifies the interactions between Ataxin-2's PAM2 motif and PABP as a critical contributor to the assembly of Ataxin-2 containing mRNP granules. This suggests a mechanism by which the interaction helps select mRNA and protein components of mRNP granules.

We suggest that Ataxin-2, guided by PAM2:PABP interactions and LSm domain interactions, recruits target mRNAs and associated proteins into translating mRNPs (Satterfield \& Pallanck, 2006). Under conditions where the translation is arrested, LSm-domain interactions are altered (Lee et al., 2017), and transcripts are released from stalled ribosomes. Base-pairing interactions between exposed mRNA side chains, as well as interactions between Ataxin-2's now accessible intrinsically disordered regions, contribute to the assembly of these mRNPs into granules. This logical sequence of events is consistent with: (a) TRIBE data showing a reduced number of edits of native Ataxin-2 target mRNAs by Atx2 $\triangle$ PAM2-ADARcd; (b) the inability of $\triangle$ PAM2-miniAtx 2 constructs to associate with stress granules; and (c) the aberrant protein composition of granules induced by Atx $2 \triangle \mathrm{PAM} 2$ in $\mathrm{S} 2$ cells. The additional observation that Atx2 $\triangle$ PAM2-ADARcd expression results in a large number of non-native mRNA edits, indicates that the PAM2:PABP interaction not only selects correct target mRNAs but also prevents Ataxin-2 engagement with incorrect mRNA target regions.

Our conclusion that Ataxin2-PAM2:PABP interactions are involved in the selection of mRNA components of RNP granules is superficially inconsistent with the observation that RNA components of native stress granules can be predicted with remarkable accuracy on the basis of mRNA size. This argues for a primary role for RNA-RNA interactions in the stress granule assembly (Jain \& Vale, 2017; Matheny et al., 2021; Van Treeck \& Parker, 2018). However, we note that experiments presented here do not address mechanisms by which mRNAs are selected into stress granules. Instead, the TRIBE data address how Atx2-target mRNAs are selected into neuronal mRNP granules that exist in non-stressed cells in vivo, and microscopic studies analyse protein components of mRNP granules formed following Atx2 expression in S2 cells. Our experiments and observations therefore point to fundamental differences in 
bioRxiv preprint doi: https://doi.org/10.1101/2022.02.15.480566; this version posted February 17, 2022. The copyright holder for this preprint (which was not certified by peer review) is the author/funder, who has granted bioRxiv a license to display the preprint in perpetuity. It is made available under aCC-BY-NC-ND 4.0 International license.

536

537

538

mechanisms by which the assembly of neuronal granules, or granule types found in unstressed cells, may differ from those involved in stress-granule assembly. The regulation and composition of the former class could well rely extensively on specific protein-protein and protein-mRNA interactions, which may be revealed by future analyses of mechanisms by which such mRNP assemblies are formed in vivo.

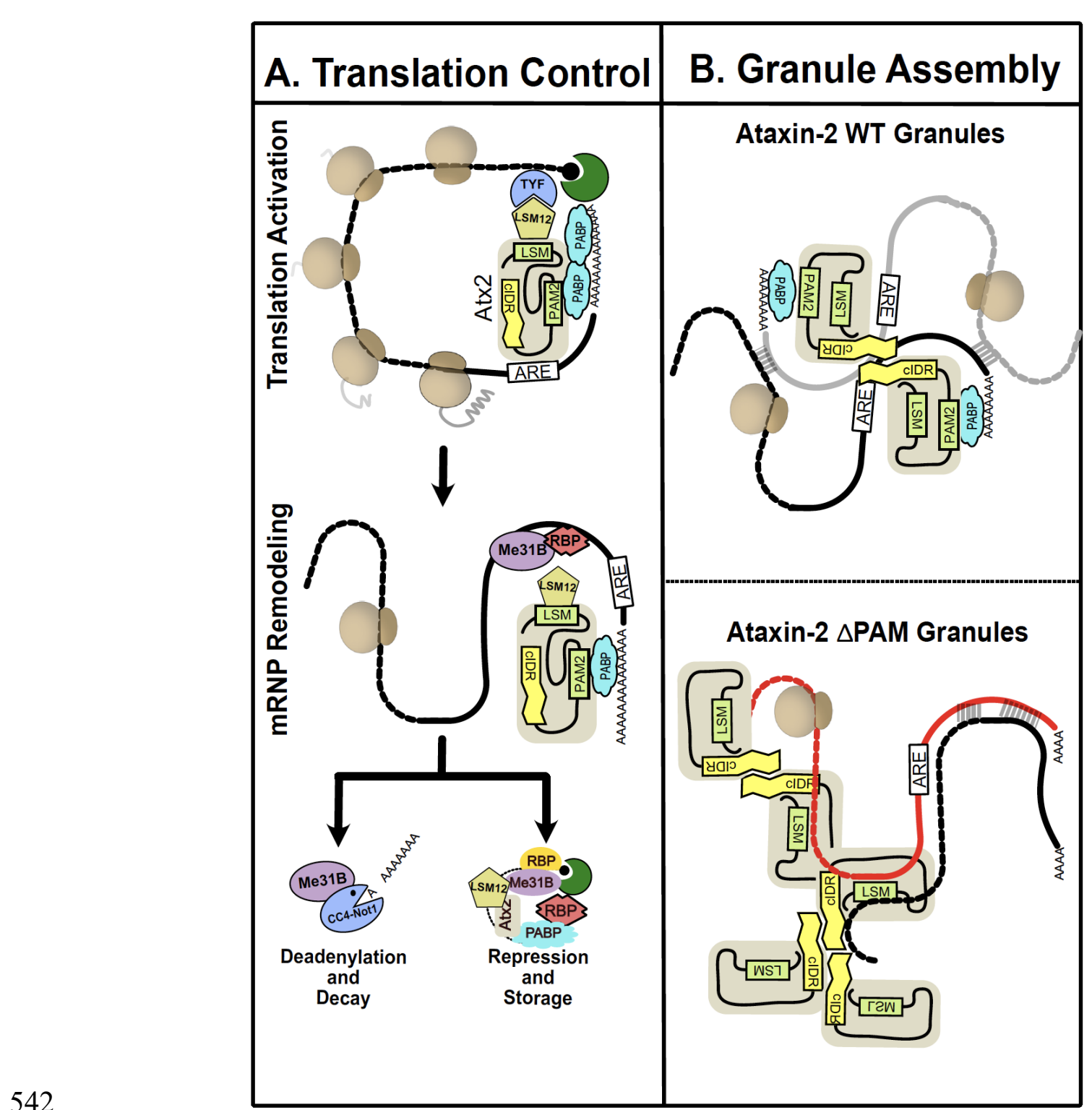

Figure 6: A model for Ataxin-2 RNP dynamics and the role of PAM2 domain in determining its RNP composition and mRNA selection. (A) Ataxin-2 is recruited to mRNAs by RBPs during different stages of the mRNA life cycle. Ataxin-2 activates translation of subsets of mRNA by recruiting LSM12, TYF and other translation activation complexes. Under specific conditions, mRNP remodelling exposes Ataxin-2 cIDR that mediates multivalent interactions and RNP granule assembly. Ataxin-2 recruits Me31B and CCR4-NOT1 complexes that lead to deadenylating and/or translation repression. It is possible that 
deadenylation can lead to degradation or translation repression and storage in RNP granules. (B) Ataxin2-PAM2 domain determines protein and RNA partners of the RNP granules. PAM2 domain is essential for recruitment of Ataxin-2 to stress granules that also contains other RBPs (eg. Me31B, FMRP, Rox8, Rin and Caprin). Ataxin-2-cIDR along with RNA-RNA interaction stabilise the stress induces RNP condensation. In the absence of the PAM2 domain, Ataxin-2 fails to recruit specific target mRNA and proteins. Remodelling of Ataxin-2 exposes the cIDR to induce phase separation and aberrant RNP condensation. The Ataxin-2 $\triangle \mathrm{PAM} 2$ granules are non-toxic and lack several known stress granule proteins (eg.FMRP, Caprin and PABP). 


\begin{tabular}{|c|c|c|c|c|}
\hline $\begin{array}{l}\text { Reagent type } \\
\text { (species) or } \\
\text { resource }\end{array}$ & Designation & $\begin{array}{l}\text { Source or } \\
\text { reference }\end{array}$ & Identifiers & $\begin{array}{l}\text { Additional } \\
\text { information }\end{array}$ \\
\hline $\begin{array}{l}\text { Genetic reagent } \\
\text { (Drosophila } \\
\text { melanogaster) }\end{array}$ & $\begin{array}{l}U A S-A t x 2-W T- \\
A D A R c d\end{array}$ & Singh et al. 2021 & N/A & \\
\hline $\begin{array}{l}\text { Genetic reagent } \\
\text { (Drosophila } \\
\text { melanogaster) } \\
\end{array}$ & $\begin{array}{l}U A S-A t x 2-\triangle L S m- \\
\text { ADARcd }\end{array}$ & Singh et al. 2021 & N/A & \\
\hline $\begin{array}{l}\text { Genetic reagent } \\
\text { (Drosophila } \\
\text { melanogaster) }\end{array}$ & $\begin{array}{l}(U A S-A t x 2-\triangle P A M 2- \\
A D A R c d)\end{array}$ & This paper & N/A & \\
\hline $\begin{array}{l}\text { Genetic reagent } \\
\text { (Drosophila } \\
\text { melanogaster) }\end{array}$ & $\begin{array}{l}\text { UAS-Atx2- } \triangle c I D R- \\
\text { ADARcd }\end{array}$ & Singh et al. 2021 & N/A & \\
\hline $\begin{array}{l}\text { Genetic reagent } \\
\text { (Drosophila } \\
\text { melanogaster) } \\
\end{array}$ & $\begin{array}{l}\text { UAS-Atx2-only } \\
L S m / L s m-A D- \\
\text { ADARcd }\end{array}$ & Singh et al. 2021 & N/A & \\
\hline $\begin{array}{l}\text { Genetic reagent } \\
\text { (Drosophila } \\
\text { melanogaster) }\end{array}$ & $\begin{array}{l}\text { mef2-Gal4; Tub- } \\
\text { Gal80 }\end{array}$ & $\begin{array}{l}\text { Bloomington Drosophila } \\
\text { Stock center }\end{array}$ & $\begin{array}{l}\text { Derived from } \\
\# 50742\end{array}$ & \\
\hline $\begin{array}{l}\text { Genetic reagent } \\
\text { (Drosophila } \\
\text { melanogaster) }\end{array}$ & $\begin{array}{l}\text { elav-Gal4; Tub- } \\
\text { Gal80 }\end{array}$ & $\begin{array}{l}\text { Bloomington Drosophila } \\
\text { Stock center }\end{array}$ & Derived from $\# 458$ & \\
\hline $\begin{array}{l}\text { Cell line (Drosophila } \\
\text { melanogaster) }\end{array}$ & $\mathrm{S} 2 \mathrm{R}+$ cells & DGRC & RRID:CVCL_Z831 & \\
\hline Cell line (Human) & HEK293T & Gift: Adrian Bracken lab & N/A & \\
\hline Cell line (Human) & $\mathrm{U} 2 \mathrm{OS}$ & $\begin{array}{l}\text { Gift: Martina Schroeder } \\
\text { lab }\end{array}$ & N/A & \\
\hline $\begin{array}{l}\text { Recombinant DNA } \\
\text { reagent }\end{array}$ & $\begin{array}{l}\text { pUASt-Atx2- } \\
\text { SNAP_fly (Plasmid) }\end{array}$ & This paper & N/A & $\begin{array}{l}\text { Construct to express fly } \\
\text { Atx2WT -SNAP }\end{array}$ \\
\hline $\begin{array}{l}\text { Recombinant DNA } \\
\text { reagent }\end{array}$ & $\begin{array}{l}\text { pUASt-ATXN2- } \\
\text { SNAP_hum (Plasmid) }\end{array}$ & This paper & N/A & $\begin{array}{l}\text { Construct to express human } \\
\text { WT ATXN2-SNAP }\end{array}$ \\
\hline $\begin{array}{l}\text { Recombinant DNA } \\
\text { reagent }\end{array}$ & $\begin{array}{l}\text { pUASt-mini-Atx2- } \\
\text { SNAP_fly (Plasmid) }\end{array}$ & This paper & N/A & $\begin{array}{l}\text { Construct to express fly } \\
\text { mini Atx2-SNAP }\end{array}$ \\
\hline $\begin{array}{l}\text { Recombinant DNA } \\
\text { reagent }\end{array}$ & $\begin{array}{l}\text { pUASt-mini-ATXN2- } \\
\text { SNAP_hum (Plasmid) }\end{array}$ & This paper & N/A & $\begin{array}{l}\text { Construct to express human } \\
\text { mini ATXN2-SNAP }\end{array}$ \\
\hline $\begin{array}{l}\text { Recombinant DNA } \\
\text { reagent }\end{array}$ & $\begin{array}{l}\text { pUASt- } \Delta \text { LSm-mini- } \\
\text { Atx2-SNAP_fly } \\
\text { (Plasmid) }\end{array}$ & This paper & N/A & $\begin{array}{l}\text { Construct to express fly } \\
\Delta \mathrm{LSm} \text { mini Atx2-SNAP }\end{array}$ \\
\hline $\begin{array}{l}\text { Recombinant DNA } \\
\text { reagent }\end{array}$ & $\begin{array}{l}\text { pUASt- } \Delta \text { LSm-mini- } \\
\text { ATXN2-SNAP_hum } \\
\text { (Plasmid) }\end{array}$ & This paper & N/A & $\begin{array}{l}\text { Construct to express human } \\
\Delta \mathrm{LSm} \text { mini ATXN2-SNAP }\end{array}$ \\
\hline $\begin{array}{l}\text { Recombinant DNA } \\
\text { reagent }\end{array}$ & $\begin{array}{l}\text { pUASt- } \Delta \text { LSmAD- } \\
\text { mini-Atx2-SNAP_fly } \\
\text { (Plasmid) }\end{array}$ & This paper & N/A & $\begin{array}{l}\text { Construct to express fly } \\
\Delta \text { LSm-AD mini Atx2- } \\
\text { SNAP }\end{array}$ \\
\hline $\begin{array}{l}\text { Recombinant DNA } \\
\text { reagent }\end{array}$ & $\begin{array}{l}\text { pUASt- } \triangle \text { LSmAD- } \\
\text { mini-ATXN2- } \\
\text { SNAP hum (Plasmid) }\end{array}$ & This paper & N/A & $\begin{array}{l}\text { Construct to express human } \\
\Delta \text { LSm-AD mini ATXN2- } \\
\text { SNAP }\end{array}$ \\
\hline $\begin{array}{l}\text { Recombinant DNA } \\
\text { reagent }\end{array}$ & $\begin{array}{l}\text { pUASt- } \triangle \text { PAM2-mini- } \\
\text { Atx2-SNAP_fly } \\
\text { (Plasmid) }\end{array}$ & This paper & N/A & $\begin{array}{l}\text { Construct to express fly } \\
\triangle \mathrm{PAM} 2 \text { mini Atx2-SNAP }\end{array}$ \\
\hline $\begin{array}{l}\text { Recombinant DNA } \\
\text { reagent }\end{array}$ & $\begin{array}{l}\text { pUASt- } \triangle \text { PAM2-mini- } \\
\text { ATXN2-SNAP_hum } \\
\text { (Plasmid) }\end{array}$ & This paper & N/A & $\begin{array}{l}\text { Construct to express human } \\
\triangle \text { PAM2 mini ATXN2- } \\
\text { SNAP }\end{array}$ \\
\hline
\end{tabular}




\begin{tabular}{|c|c|c|c|c|}
\hline $\begin{array}{l}\text { Recombinant DNA } \\
\text { reagent }\end{array}$ & $\begin{array}{l}\text { pUASt-L859A-mini- } \\
\text { Atx2-SNAP_fly } \\
\text { (Plasmid) }\end{array}$ & This paper & N/A & $\begin{array}{l}\text { Construct to express fly } \\
\text { PAM2* L859A mini Atx2- } \\
\text { SNAP }\end{array}$ \\
\hline $\begin{array}{l}\text { Recombinant DNA } \\
\text { reagent }\end{array}$ & $\begin{array}{l}\text { pUASt-L914A-mini- } \\
\text { ATXN2-SNAP_hum } \\
\text { (Plasmid) }\end{array}$ & This paper & N/A & $\begin{array}{l}\text { Construct to express human } \\
\text { PAM2* L914A mini } \\
\text { ATXN2-SNAP }\end{array}$ \\
\hline $\begin{array}{l}\text { Recombinant DNA } \\
\text { reagent }\end{array}$ & $\begin{array}{l}\text { pUASt-F866A-mini- } \\
\text { Atx2-SNAP_fly } \\
\text { (Plasmid) }\end{array}$ & This paper & N/A & $\begin{array}{l}\text { Construct to express fly } \\
\text { PAM2* F866A mini Atx2- } \\
\text { SNAP }\end{array}$ \\
\hline $\begin{array}{l}\text { Recombinant DNA } \\
\text { reagent }\end{array}$ & $\begin{array}{l}\text { pUASt-F921A-mini- } \\
\text { ATXN2-SNAP_hum } \\
\text { (Plasmid) }\end{array}$ & This paper & N/A & $\begin{array}{l}\text { Construct to express human } \\
\text { PAM2* F921A mini } \\
\text { ATXN2-SNAP }\end{array}$ \\
\hline $\begin{array}{l}\text { Recombinant DNA } \\
\text { reagent }\end{array}$ & $\begin{array}{l}\text { pUASt-L859A- } \\
\text { F866A-mini-Atx2- } \\
\text { SNAP_fly (Plasmid) }\end{array}$ & This paper & N/A & $\begin{array}{l}\text { Construct to express fly } \\
\text { PAM2* L859A and F866A } \\
\text { mini Atx2-SNAP }\end{array}$ \\
\hline $\begin{array}{l}\text { Recombinant DNA } \\
\text { reagent }\end{array}$ & $\begin{array}{l}\text { pUASt-L914A- } \\
\text { F921A-Q928A-mini- } \\
\text { ATXN2-SNAP_hum } \\
\text { (Plasmid) }\end{array}$ & This paper & N/A & $\begin{array}{l}\text { Construct to express human } \\
\text { PAM2* L914A, F921A } \\
\text { and Q928A mini ATXN2- } \\
\text { SNAP }\end{array}$ \\
\hline $\begin{array}{l}\text { Recombinant DNA } \\
\text { reagent }\end{array}$ & $\begin{array}{l}\text { pAcman-Atx2-GFP } \\
\text { (Fosmid) }\end{array}$ & Sudhakaran et al. 2013 & N/A & $\begin{array}{l}\text { Genomic construct to } \\
\text { express fly WT Atx2-GFP }\end{array}$ \\
\hline $\begin{array}{l}\text { Recombinant DNA } \\
\text { reagent }\end{array}$ & $\begin{array}{l}\text { pAcman- } \Delta \text { LSm-Atx2- } \\
\text { GFP (Fosmid) }\end{array}$ & This paper & N/A & $\begin{array}{l}\text { Genomic construct to } \\
\text { express fly } \Delta \text { LSm Atx2- } \\
\text { GFP }\end{array}$ \\
\hline $\begin{array}{l}\text { Recombinant DNA } \\
\text { reagent }\end{array}$ & $\begin{array}{l}\text { pAcman- } \triangle \text { PAM2- } \\
\text { Atx2-GFP (Fosmid) }\end{array}$ & This paper & N/A & $\begin{array}{l}\text { Genomic construct to } \\
\text { express fly } \triangle \text { PAM2 Atx2- } \\
\text { GFP }\end{array}$ \\
\hline $\begin{array}{l}\text { Recombinant DNA } \\
\text { reagent }\end{array}$ & pActin-Gal4 & DGRC & & $\begin{array}{l}\text { Actin promoter Gal4 for } \\
\text { insect UAS expression }\end{array}$ \\
\hline $\begin{array}{l}\text { Recombinant DNA } \\
\text { reagent }\end{array}$ & pCMV-Gal4 & Addgene & \#24345 & $\begin{array}{l}\text { CMV promoter Gal4 for } \\
\text { mammalian UAS } \\
\text { expression }\end{array}$ \\
\hline \multirow{2}{*}{ Antibody } & \multirow{2}{*}{$\begin{array}{l}\text { Anti-Atx2 (chicken } \\
\text { polyclonal) }\end{array}$} & \multirow{2}{*}{$\begin{array}{l}\text { Bakthavachalu et al., } \\
2018\end{array}$} & \multirow{2}{*}{ N/A } & IF $(1: 1000)$ \\
\hline & & & & WB $(1: 1000)$ \\
\hline Antibody & $\begin{array}{l}\text { Anti-Caprin (rabbit } \\
\text { polyclonal) }\end{array}$ & Papoulas et al., 2010 & N/A & IF $(1: 1000)$ \\
\hline Antibody & $\begin{array}{l}\text { Anti-dFMR (mouse } \\
\text { monoclonal) }\end{array}$ & DSHB & \# 5A11 & $\begin{array}{l}\text { IF }(1: 1000) \text { deposited to } \\
\text { the DSHB by Siomi, H. }\end{array}$ \\
\hline Antibody & $\begin{array}{l}\text { Anti-GFP (chicken } \\
\text { polyclonal) }\end{array}$ & Abcam & Cat\# mAb 13970 & IF $(1: 1000)$ \\
\hline \multirow{2}{*}{ Antibody } & \multirow{2}{*}{$\begin{array}{l}\text { Anti-V5 (rabbit } \\
\text { polyclonal) }\end{array}$} & \multirow{2}{*}{$\begin{array}{l}\text { Santa Cruz } \\
\text { Biotechnology }\end{array}$} & \multirow{2}{*}{ Cat\# sc83849-R } & IF $(1: 1000)$ \\
\hline & & & & WB $(1: 1000)$ \\
\hline Antibody & $\begin{array}{l}\text { PABP (rabbit } \\
\text { polyclonal serum) }\end{array}$ & Lee et al. 2017 & N/A & $\begin{array}{l}\text { IF }(1: 500) \\
(1: 500)\end{array}$ \\
\hline Antibody & $\begin{array}{l}\text { Me31B (rabbit } \\
\text { polyclonal serum) }\end{array}$ & Lee et al. 2018 & N/A & IF (1:500) \\
\hline Antibody & Rox8 (rat polyclonal) & Buddika et al. 2020 & N/A & IF $(1: 1000)$ \\
\hline Antibody & $\begin{array}{l}\text { SNAP (rabbit } \\
\text { polyclonal) }\end{array}$ & NEB & Cat\# P9310S & WB $(1: 1000)$ \\
\hline Antibody & $\begin{array}{l}\text { PABPC1 (rabbit } \\
\text { polyclonal) }\end{array}$ & Abcam & Cat\# ab21060 & WB (1:1000) \\
\hline Antibody & $\begin{array}{l}\text { LSM12 (rabbit anti } \\
\text { human polyclonal) }\end{array}$ & Abcam & Cat\# ab173292 & WB (1:1000) \\
\hline Antibody & $\begin{array}{l}\text { G3BP (mouse } \\
\text { monoclonal) }\end{array}$ & BD Bioscience & Cat\# 611126 & IF $(1: 1000)$ \\
\hline Antibody & $\begin{array}{l}\text { Histone H3 (rabbit } \\
\text { polyclonal) }\end{array}$ & Cell signaling tech & Cat\# 9715 & WB (1:1000) \\
\hline Antibody & $\begin{array}{l}\text { Baf155 (rabbit } \\
\text { monoclonal) }\end{array}$ & Cell signaling tech & Cat\# 11956 & WB (1:1000) \\
\hline
\end{tabular}


bioRxiv preprint doi: https://doi.org/10.1101/2022.02.15.480566; this version posted February 17, 2022. The copyright holder for this preprint (which was not certified by peer review) is the author/funder, who has granted bioRxiv a license to display the preprint in perpetuity. It is made available under aCC-BY-NC-ND 4.0 International license.

\begin{tabular}{|c|c|c|c|c|}
\hline Antibody & HRP Goat anti-rabbit & Invitrogen & Cat\# A16104 & WB $(1: 10,000)$ \\
\hline Antibody & HRP Goat anti-mouse & Invitrogen & Cat\# 31430 & WB $(1: 10,000)$ \\
\hline Antibody & $\begin{array}{l}\text { Alexa Fluor } 555 \\
\text { (polyclonal goat anti- } \\
\text { chicken IgG) }\end{array}$ & Invitrogen & Cat\# A21437 & IF $(1: 1000)$ \\
\hline Antibody & $\begin{array}{l}\text { Alexa Fluor } 488 \\
\text { (polyclonal goat anti- } \\
\text { chicken IgG) }\end{array}$ & Invitrogen & Cat\# A11039 & IF $(1: 1000)$ \\
\hline Antibody & $\begin{array}{l}\text { Alexa Fluor } 647 \\
\text { (polyclonal goat anti- } \\
\text { chicken IgG) }\end{array}$ & Invitrogen & Cat\# A21449 & IF $(1: 1000)$ \\
\hline Antibody & $\begin{array}{l}\text { Alexa Fluor } 555 \\
\text { (polyclonal goat anti- } \\
\text { rabbit IgG) }\end{array}$ & Invitrogen & Cat\# A21428 & IF $(1: 1000)$ \\
\hline Antibody & $\begin{array}{l}\text { Alexa Fluor } 488 \\
\text { (polyclonal goat anti- } \\
\text { rabbit IgG) }\end{array}$ & Invitrogen & Cat\# A11078 & IF $(1: 1000)$ \\
\hline Antibody & $\begin{array}{l}\text { Alexa Fluor } 647 \\
\text { (polyclonal goat anti- } \\
\text { rabbit IgG) }\end{array}$ & Invitrogen & Cat\# A21244 & IF $(1: 1000)$ \\
\hline Antibody & $\begin{array}{l}\text { Alexa Fluor } 555 \\
\text { (polyclonal goat anti- } \\
\text { mouse IgG) }\end{array}$ & Invitrogen & Cat\# A21422 & IF $(1: 1000)$ \\
\hline \multirow[b]{2}{*}{ Antibody } & Alexa Fluor 488 & \multirow[b]{2}{*}{ Invitrogen } & \multirow[b]{2}{*}{ Cat\# A21121 } & \multirow[b]{2}{*}{ IF $(1: 1000)$} \\
\hline & $\begin{array}{l}\text { (polyclonal goat anti- } \\
\text { mouse IgG) }\end{array}$ & & & \\
\hline Antibody & $\begin{array}{l}\text { Alexa Fluor } 647 \\
\text { (polyclonal goat anti- } \\
\text { mouse IgG) }\end{array}$ & Invitrogen & Cat\# A21235 & IF $(1: 1000)$ \\
\hline Chemical compound & $\begin{array}{l}\text { MOWIOL mounting } \\
\text { medium }\end{array}$ & Sigma (Merck) & Cat\# 81381 & \\
\hline Chemical compound & SNAP-TmrStar & New England Biolabs & Cat\# S9105S & IF $(1: 1000)$ \\
\hline Chemical compound & SNAP-Surface 488 & New England Biolabs & Cat\# S9124S & IF $(1: 1000)$ \\
\hline Software, algorithm & TRIBE & McMahon et al., 2016 & $\begin{array}{l}\text { https://github.com/ro } \\
\text { sbashlab/TRIBE }\end{array}$ & \\
\hline Software, algorithm & STAR v2.5.3 & Dobin et al., 2013 & $\begin{array}{l}\text { https://github.com/ale } \\
\text { xdobin/STAR }\end{array}$ & \\
\hline Software, algorithm & HTSeq v0.11.2 & Anders et al., 2015 & $\begin{array}{l}\text { https://github.com/hts } \\
\text { eq/htseq }\end{array}$ & \\
\hline Software, algorithm & DESeq2 & Love et al., 2014 & $\begin{array}{l}\text { https://bioconductor. } \\
\text { org/packages/release/ } \\
\text { bioc/html/DESeq2.ht } \\
\mathrm{ml}\end{array}$ & \\
\hline Software, algorithm & AREScore & Spasic et al., 2012 & $\begin{array}{l}\text { http://arescore.dkfz.d } \\
\text { e/arescore.pl }\end{array}$ & \\
\hline Software, algorithm & Guitar & Cui et al., 2016 & $\begin{array}{l}\text { https://bioconductor. } \\
\text { org/packages/release/ } \\
\text { bioc/html/Guitar.html }\end{array}$ & \\
\hline Software, algorithm & Bedtools & Quinlan and Hall, 2010 & $\begin{array}{l}\text { https://github.com/ar } \\
\text { q5x/bedtools2 }\end{array}$ & \\
\hline Software, algorithm & twoBitToFa & - & $\begin{array}{l}\text { https:/genome.ucsc.e } \\
\text { du/goldenPath/help/t } \\
\text { woBit.html }\end{array}$ & \\
\hline Software, algorithm & MEME suite & Bailey et al., 2009 & $\begin{array}{l}\text { http://meme- } \\
\text { suite.org/tools/meme }\end{array}$ & \\
\hline Software, algorithm & ImageJ & Schneider et al., 2012 & $\begin{array}{l}\text { https://imagej.nih.gov } \\
\text { /ij/ }\end{array}$ & \\
\hline
\end{tabular}




\begin{tabular}{|l|l|l|l|l|}
\hline Software, algorithm & Ggplot2 & Wilkinson, 2011 & $\begin{array}{l}\text { https://github.com/tid } \\
\text { yverse/ggplot2 }\end{array}$ & \\
\hline Software, algorithm & Pheatmap & & $\begin{array}{l}\text { https://cran.r- } \\
\text { project.org/web/pack } \\
\text { ages/pheatmap/index. } \\
\text { html }\end{array}$ & \\
\hline Software, algorithm & SnapDragon & & $\begin{array}{l}\text { https://www.flyrnai.o } \\
\text { rg/snapdragon }\end{array}$ & \\
\hline
\end{tabular}

565 Cell culture, transfection and stress induction

566 Drosophila S2R+ cells were obtained from the DGRC, Indiana University, and were grown in

567 Gibco Schneider's S2 media with $10 \%$ FBS and $1 \%$ penicillin and streptomycin, at $25^{\circ} \mathrm{C}$.

568 Transfections were performed using either FugeneHD (Active Motif) or TransIT-X2 (Mirus)

569 reagents at 2:1 ratio $\mu \mathrm{l}$ reagent to $\mu$ g plasmid DNA for 24-72 $\mathrm{h}$ depending on downstream use.

570 HEK293T cells from Adrian Bracken, Trinity College Dublin, were grown in Gibco

571 Dulbecco's Modified Eagle Media with 10\% FBS, 2 mM l-glutamine addition, 1\% penicillin

572 and streptomycin, at $37^{\circ} \mathrm{C}$ and 5\% CO2. U2OS cells from Martina Schroeder, Maynooth

573 University, were grown at the same conditions as HEK293T. Mammalian cell transfections

574 were carried out with $1 \mathrm{mM}$ PEI (Polysciences) solution at 2:1 ratio $\mu 1$ reagent to $\mu \mathrm{g}$ plasmid

575 DNA for 24-72H depending on downstream use. For confocal imaging applications cells were 576 grown in 24-well plates on glass cover-slips for $24 \mathrm{~h}$ before transfection for up to $48 \mathrm{~h}$. For

577 Western blotting and IP, cells were grown in $75 \mathrm{~cm}^{2}$ flasks until $>80 \%$ confluent before

578 transfection for up to $72 \mathrm{H}$ before harvesting. Oxidative stress was induced in Drosophila $\mathrm{S} 2 \mathrm{R}+$

579 cells with addition of sodium arsenite solution to a final concentration of $50 \mu \mathrm{M}$ in media for

$5803 \mathrm{~h}$. In mammalian cells, oxidative stress was induced in the same way except for only $1 \mathrm{~h}$.

582 Western blotting and protein immunoprecipitation

583 Total protein extracts were prepared from S2 and HEK293 cells as described earlier 584 (Sudhakaran et al., 2014). Up to $10 \mu \mathrm{g}$ total protein was loaded per well for detecting Atx2585 SNAP constructs, partner proteins and loading controls on 8-12\% SDS-PAGE gels and 586 transferred to nitrocellulose membranes. The blots were probed in 5\% skim milk in PBS using 587 rabbit anti-SNAP (1:1000), rabbit anti-PABP (1:1000), rabbit anti-LSM12 (1:1000) antibodies, 588 and mouse anti-histone H3 (1:5000) and mouse anti-BAF155 (1:2000) loading control 589 antibodies. Corresponding HRP-conjugated secondary antibodies were used at 1:10,000 590 dilution and developed using Pierce ECL western blotting substrate (ThermoFisher) as per the 591 manufacturer's instructions. 
For Atx2-SNAP construct immunoprecipitation, transfected cell lysates were normalised to the same volume and concentration, $10 \%$ of the volume was saved and diluted as an input control, and Chromotek anti-SNAP-tag conjugated agarose beads and IP kits were used according to the manufacturer's specifications. Pulled-down proteins together with corresponding sample input controls were blotted as described above.

Immunohistochemistry and imaging of cultured cells

Transfected cells on coverslips were fixed with 4\% paraformaldehyde in PBS solution for 15 0.5\% TritonX100 in PBS solution for $3 \mathrm{~min}$, before three more $5 \mathrm{~min}$ washes in PBS. Cells were blocked with 3\% BSA in PBS for $1 \mathrm{~h}$ at room temperature before staining with primary antibodies at appropriate dilutions in $3 \% \mathrm{BSA}$ overnight at $4{ }^{\circ} \mathrm{C}$. Corresponding fluorescent secondary antibodies in 3\% BSA were used to stain the sample cells for $1 \mathrm{~h}$ at room temperature after primaries were washed off. Where SNAP-tagged proteins were being visualized, SNAPligand TMR-Star (NEB) or SNAP-surface-Alexa488 (NEB) were added at the secondary antibody staining stage. Following staining and washing, cells were mounted upside-down on microscopy slides in MOWIOL, allowed to cure for $>12 \mathrm{~h}$ at $4{ }^{\circ} \mathrm{C}$, and imaged on a Zeiss LSM880 Airyscan/AiryscanFast confocal microscope with a 20x air objective.

\section{Bioimage analysis}

612 Where relevant, Airyscan images were processed with Zen Black software (Zeiss) with 613 recommended settings. Confocal microscopy images were analysed using macros within 614 ImageJ/FIJI and Excel. Quantification of co-localisation was performed by comparing stress 615 granule marker staining intensity profiles across a randomised selection of Atx2 granules 616 within transfected cells, with the intensity profile of the Atx2 staining. Any signal 10\% or 617 higher than background (adjusted for fluorophore bleed through) was deemed evidence of co-

618 localisation within that particular granule. For quantifying the exclusion of mini-Atx2-SNAP 619 constructs from stress induced granules the Caprin or G3BP1 staining was used as independent 620 identifier of stress granules and Atx2 profiles were compared to them. 48-120 granules were 621 quantified in each co-staining (Figure 2), and 28-70 granules were quantified for each construct 622 transfection (Figure 4). 
625 Threading of the Drosophila PAM2 peptide bound to the MLLE domain of PABPC1 was

626 performed using the Swiss-PdbViewer software, based on the human crystal structure of the

627 complex obtained from PDB, identified as 3KTR (Kozlov et al., 2010)

628

629 Experimental fly crosses

630 Drosophila stocks were maintained at $25^{\circ} \mathrm{C}$ in corn meal agar. Strains homozygous for UAS631 transgenes were crossed with elav-Gal4 and tub-Gal80ts at $18{ }^{\circ} \mathrm{C}$ till the adult fly emerged. 632 The flies were shifted to $29{ }^{\circ} \mathrm{C}$ for 5 days before processing for RNA extraction for TRIBE 633 experiments. The climbing behaviour experiments were performed on flies kept at $29{ }^{\circ} \mathrm{C}$ for 634 either 1 or 15 days. For microCT experiments, the UAS-transgenes were crossed with mef2635 Gal4 and tub-Gal80ts at $18^{\circ} \mathrm{C}$ and the adult flies were transferred to $29^{\circ} \mathrm{C}$ for 1 day or 20 days. 636

\section{RNA extraction from brain and NGS}

638 Around 10-12 adult brains were dissected in RNA Later for total RNA isolation. RNA was isolated using TRIzol reagent (Invitrogen) as per the manufacturer's protocol. Poly(A)enriched mRNA was used to prepare Illumina libraries using the NEBNext Ultra II Directional

641 RNA Library Prep kit (E7765L). Atx2- $\triangle$ PAM2-ADARcd samples were sequenced with 642 Illumina HiSeq PE Rapid Cluster Kit v2 (PE-402-4002) to generate $2 \times 100$ paired-end strand643 specific data using the Illumina HiSeq 2500 sequencing platform.

645 TRIBE data analysis

646 The sequencing reads obtained had a mean quality score (Q-Score) $>=37$. Analysis of the 647 TRIBE data was performed as described previously (McMahon et al., 2016, Singh et al., 2021). 648 Briefly, the reference genome and gtf file of Drosophila melanogaster, version dm6, were 649 downloaded from the UCSC genome browser. Raw sequencing reads were mapped using 650 TopHat2 (Trapnell et al, 2009) with the parameters '--library-type fr-firststrand -m 1 N 3 -651 read-edit-dist 3 p 5 g 2 -I 50000 --microexon-search --no-coverage-search -G dm6_genes.gtf'. 652 Only uniquely mapped reads are considered for editing analysis. A table of raw and mapped 653 reads is included in Supplementary Table 1. A threshold file was created by ensuring only edits 654 with coverage of at least 20 reads and 15\% edits were retained. All the TRIBE experiments 655 were performed in duplicates, and only the edits identified in both replicates above the edit 656 threshold are reported.

657 Climbing Assay: 
658 Appropriately aged adult Drosophila was transferred to a $50 \mathrm{ml}$ graduated glass measuring

659 cylinder for the climbing assay and sealed with a cotton plug. A digital video camera was

660 positioned to record the vials. The assay was initiated by tapping the cylinder against a foam

661 pad to collect the flies to the bottom of the cylinder and the flies were allowed to climb the

662 cylinder with video being recorded for $\sim 30 \mathrm{~s}$. The number of flies that crossed the $20 \mathrm{ml}$ mark

$663(\sim 5.5 \mathrm{~cm})$ was counted over time and the data was plotted against the time using GraphPad

664 prism. Average of 3 trials were used for each biological replicate. 7-10 biological replicates

665 were used for each genotype.

666

667 Sample preparation and scanning for microCT:

668 Drosophila indirect flight muscle microCT was carried out as described in Chaturvedi et. al, 669 2019. Briefly, animals were anesthetized on ice and fixed in PBS containing 4\% 670 paraformaldehyde (PFA). Thoraces were dissected and stained using 1\% elemental iodine 671 (1.93900.0121, Emparta, Merck) with 2\% potassium iodide (no. 15724 , Qualigens) dissolved 672 in PBS. The stained samples were washed in PBS and embedded in petroleum jelly. MicroCT 673 scanning was carried out at $40 \mathrm{kV}, 250 \mu \mathrm{A}$, on Bruker Skyscan-1272.

674

675 Data availability

676 The RNA sequencing data have been deposited to GEO under the accession code GSE196739.

678

679 Contact for reagent and resource sharing

680 Further information and requests for resources and reagents should be directed to and will be 681 fulfilled by the lead contacts Mani Ramaswami (mani.ramaswami@tcd.ie) and Baskar 682 Bakthavachalu (baskar@iitmandi.ac.in).

683

ACKNOWLEDGEMENTS:

685

686 We thank members of the Ramaswami, Vijay Raghavan and Bakthavachalu labs and Roy 687 Parker for useful discussions and/or comments on the manuscript. We thank Marlena Mucha, 688 Adrian Bracken and Amir Khan for advice and help with biochemical experiments, Michael 689 Rosbash for Drosophila TRIBE plasmids, and colleagues acknowledged in the Key Resources 690 table for reagents and advice. The fly facility at Bangalore Life Science Cluster (BLiSC) 
provided support with fly stock supply as well as generation of transgenic; CIFF at BLiSC provided essential confocal microscopy support; and Awadhesh Pandit and next-generation genomics facility at BLiSC provided NGS service. Daniel Fortunati thanks Kenneth Mok for his mentorship. We acknowledge Drosophila Genomics Resource Centre (supported by NIH grant 2P40OC010949) for Drosophila S2 cells.

FUNDING:

698 The work was supported by a Science Foundation Ireland (SFI) Investigator grant to MR and 699 NCBS-TIFR intramural funding to KVR. BB is supported by the DBT/Wellcome Trust India 700 Alliance Fellowship (IA/I/19/1/504286). We acknowledge the support from an Irish Research 701 Council Postgraduate Fellowship to DF, the J. C. Bose Fellowship of the Government of India (KVR), INSA Young Scientist Project (INSA/SP/YSP/143/2017) (AS), SERB to MR from a collaborative VAJRA award to Dr. Raghu Padinjat, and a DST INSPIRE fellowship (KA). We thank C-CAMP for logistical support for SSP.

\section{AUTHOR CONTRIBUTIONS:}

707 Conceptualization, A.P., D.F, A.S., J.Huelsmeier, K.V.R., M.R., and B.B.; Methodology, A.P., 708 D.F, A.S., J.Huelsmeier, A.R.K., S.S.P., J.Hillebrand, K.A., D.J., G.B., J.L., C.L., G.A., 709 K.H.M., K.V.R., M.R., and B.B.; Investigation, A.S., J.Huelsmeier, A.R.K., S.S.P., 710 J.Hillebrand, A.P., K.A., K.V.R., M.R., and B.B.; Writing-Original Draft, A.P., D.F, A.S., 711 J.Huelsmeier, K.V.R., M.R., and B.B.; Writing-Review \& Editing, A.P., D.F, A.S., 712 J.Huelsmeier, A.R.K., S.S.P., J.Hillebrand, K.A., D.J., G.B., J.L., C.L., G.A., K.H.M., K.V.R., 713 M.R., and B.B.; Funding Acquisition, K.V.R., M.R., and B.B.; Resources, Fly community.

715 DECLARATION OF INTERESTS: The authors declare no conflicts of interest. 
SUPPLEMENTARY FIGURES:

\section{Supplementary Figure 1:}

A.
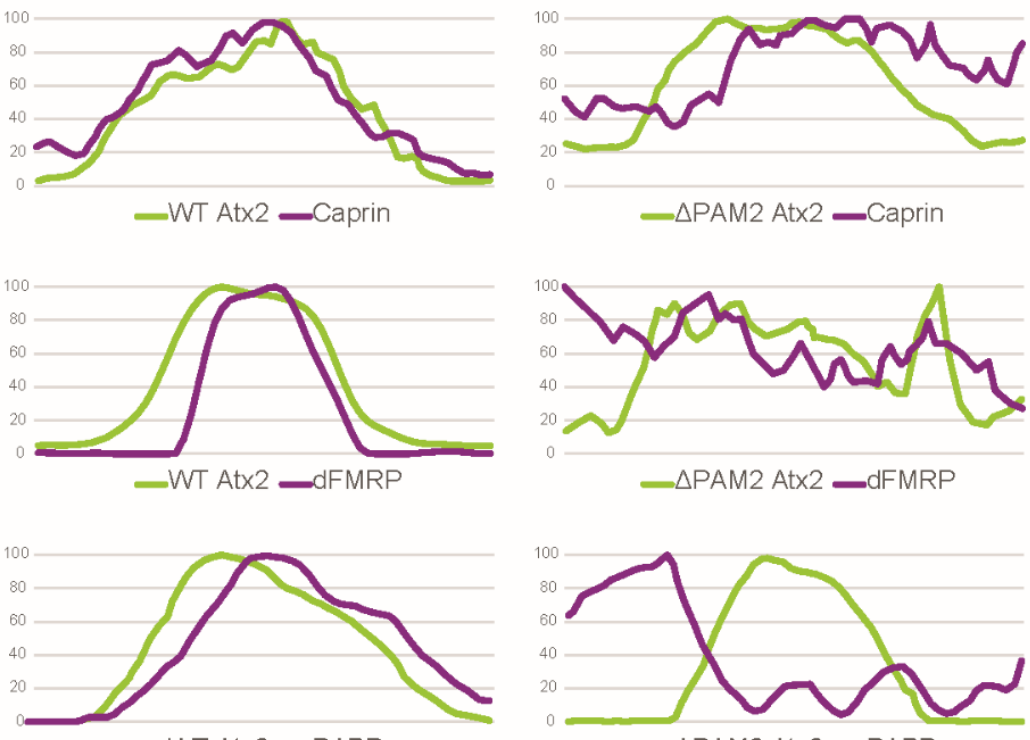

- WT Atx2 $\longrightarrow$ PABP

$\triangle P A M 2$ Atx2 $\rightarrow P A B P$

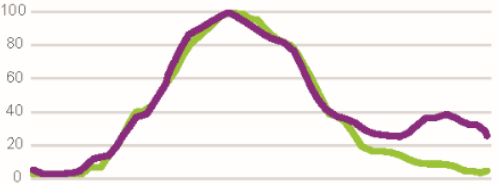

$=$ WT Atx2 Me31B

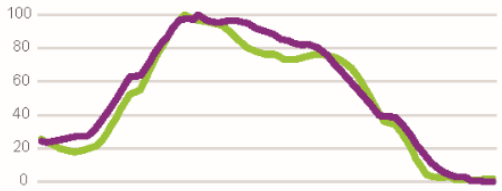

$-\triangle \mathrm{PAM} 2 \mathrm{Atx} 2 \mathrm{Me} 31 \mathrm{~B}$
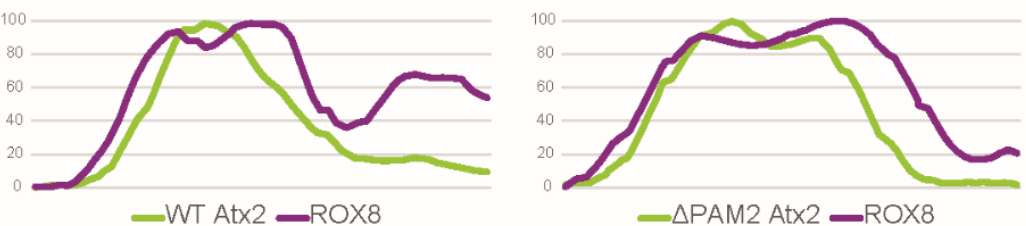

B. Co-localisation of signal enrichment in granules

\begin{tabular}{|l|l|l|}
\hline \multicolumn{3}{|c|}{ Co-localisation of signal enrichment in granules } \\
\hline & WT Atx2 & DPAM2 Atx2 \\
\hline Caprin & $100.0 \%$ & $7.1 \%$ \\
\hline dFMRP & $100.0 \%$ & $2.4 \%$ \\
\hline PABP & $76.7 \%$ & $14.6 \%$ \\
\hline Me31B & $66.7 \%$ & $52.0 \%$ \\
\hline Rox8 & $100 \%$ & $100 \%$ \\
\hline
\end{tabular}

C.

\begin{tabular}{|c|c|c|c|c|c|c|c|}
\hline \multirow[b]{2}{*}{ Construct } & \multicolumn{7}{|c|}{ Drosophila Mini At×2-SNAP Version } \\
\hline & WT & $\Delta \mathrm{LSm}$ & $\Delta \mathrm{LSm}-\mathrm{AD}$ & $\triangle \mathrm{PAM} 2$ & L859A & F866A & Double* \\
\hline \multirow[t]{2}{*}{$\%$ enrichment in SGs } & $88.60 \%$ & $80.00 \%$ & $93.30 \%$ & $4.60 \%$ & $0.00 \%$ & $0.00 \%$ & $0.00 \%$ \\
\hline & \multicolumn{7}{|c|}{ Human Mini Atxn2-SNAP Version } \\
\hline Construct & WT & $\Delta L S m$ & $\Delta \mathrm{LSm}-\mathrm{AD}$ & $\triangle \mathrm{PAM} 2$ & L914A & F921A & Triple* \\
\hline$\%$ enrichment in SGs & $100.00 \%$ & $96.20 \%$ & $100.00 \%$ & $4.90 \%$ & $0.00 \%$ & $5.00 \%$ & $4.80 \%$ \\
\hline
\end{tabular}

Supplementary Figure 1: Co-localisation quantification for figure 2, figure 4. (A) Normalised profile plots of Atx2-GFP granules in S2 cells as shown in Figure 2. Within representative granules of wild type Atx2-GFP (green line), SG components Caprin, dFMRP, PABP, Me31B, and Rox 8 show largely overlapping enrichment of fluorescence profile along a line bisecting a granule after immunohistochemistry and imaging (purple line). In Atx2 $\triangle$ PAM2-GFP granules, 
727 this colocalization of fluorescence signals is not seen in the case of Caprin, dFMRP and PABP,

728 suggesting these components are not enriched in these granules above background level. (B)

729 Quantification of co-localization for Figure 2. $\mathrm{N}=48-120$ images of Atx2-GFP granules were

730 randomly selected for each co-staining and analysed for signal co-enrichment (see methods) in

731 the case of each component assayed. (C) Quantification of Atx2 construct inclusion in SGs for

732 Figure $4 . \mathrm{N}=28-70$ images of stress granules in arsenite stressed $\mathrm{S} 2$ cells (marked by anti-

733 Caprin staining) and U2OS cells (marked by anti-G3BP staining) were randomly selected for

734 each Atx2 construct assayed and were analysed for Mini Atx2-SNAP allele signal co-

735 enrichment (see methods).

736 
bioRxiv preprint doi: https://doi.org/10.1101/2022.02 15.480566: this version posted February 17 2022. The copyright holder for this preprint (which was not certified by peer review) is the author/funder, who has granted bioRxiv a license to display the preprint in perpetuity. It is made available under aCC-BY-NC-ND 4.0 International license.

\section{Supplementary Figure 2:}
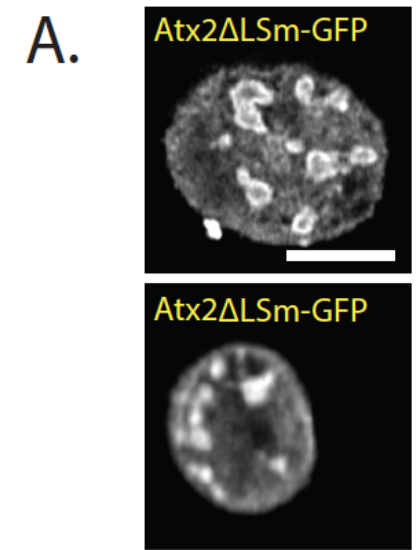

Atx2LLSm-GFP

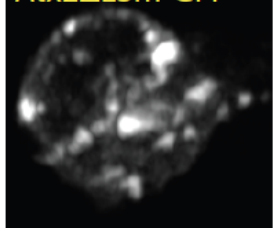

Atx2 $\Delta$ LSm-GFP
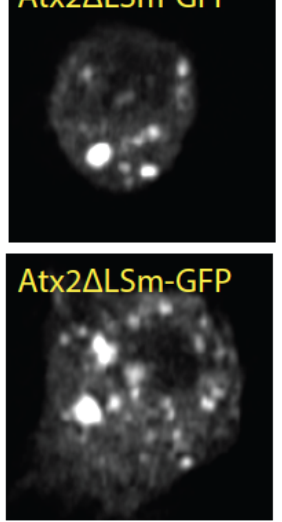
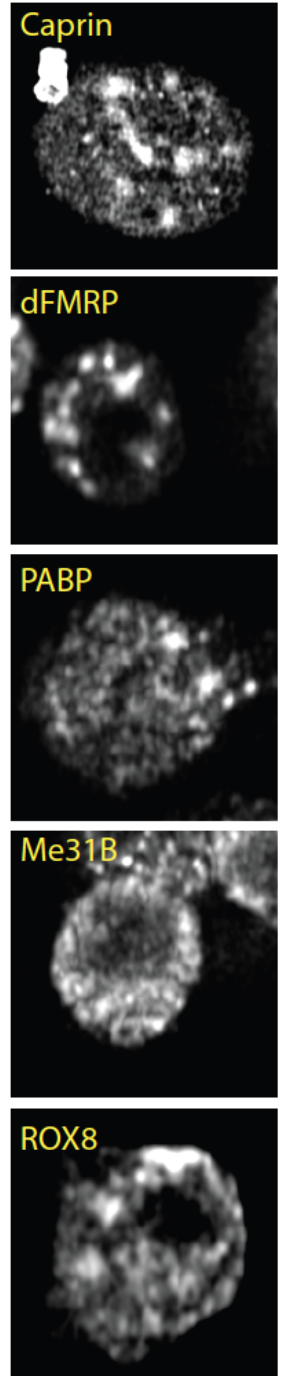

739 Supplementary Figure 2: Atx2 $\Delta$ LSm granules in S2 cells do not show significantly altered 740 protein contents compared to wild-type Atx2. Caprin, dFMRP, PABP, Me31B, and Rox8 co-

741 localize with overexpressed Atx2 $\Delta$ LSm GFP, suggesting that the granules formed contain a

742 similar set of components as Atx2 granules. It should be noted that Atx2 granules do not 743 sequester the majority of the endogenous components stained for, leading to a high, diffuse 744 background staining. 


\section{Supplementary Figure 3:}

A.

PAM2 domain

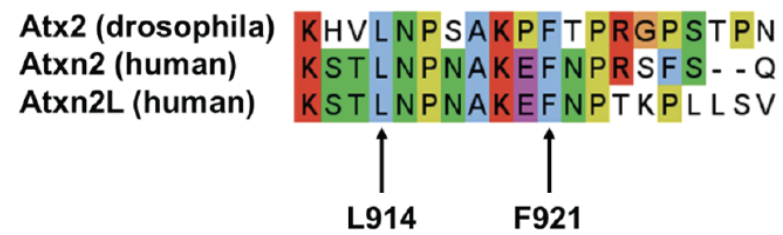

B.

MLLE domain

PABP (drosophila) EKL I ASL LANAKPQEQKQ I LGERLYPM I EHMHANLAGK I TGML LE I ENSEL LH

749 Supplementary Figure 3: The ATXN2 PAM2 and the PABPC1 MLLE domain are highly 750 conserved from fly to human. (A) The ATXN2 PAM2 domain exhibits high sequence 751 similarity where the key MLLE domain hydrophobic binding residues leucine 914 and 752 phenylalanine 921 (human ATXN2 numbering) are conserved from Drosophila to humans. (B) 753 Its binding partner, the PABPC1 MLLE domain, is also highly conserved from Drosophila to 754 human. Sequence IDs: Q8SWR8 (Atx2_DROME), Q99700 (ATXN2_HUMAN), Q8WWM7 755 (ATX2L_HUMAN), P21187 (PABP_DROME), P11940 (PABP1_HUMAN). 
bioRxiv preprint doi: https://doi.org/10.1101/2022.02 15.480566: this version posted February 17,2022. The copyright holder for this preprint (which was not certified by peer review) is the author/funder, who has granted bioRxiv a license to display the preprint in perpetuity. It is made available under aCC-BY-NC-ND 4.0 International license.

\section{Supplementary Figure 4:}

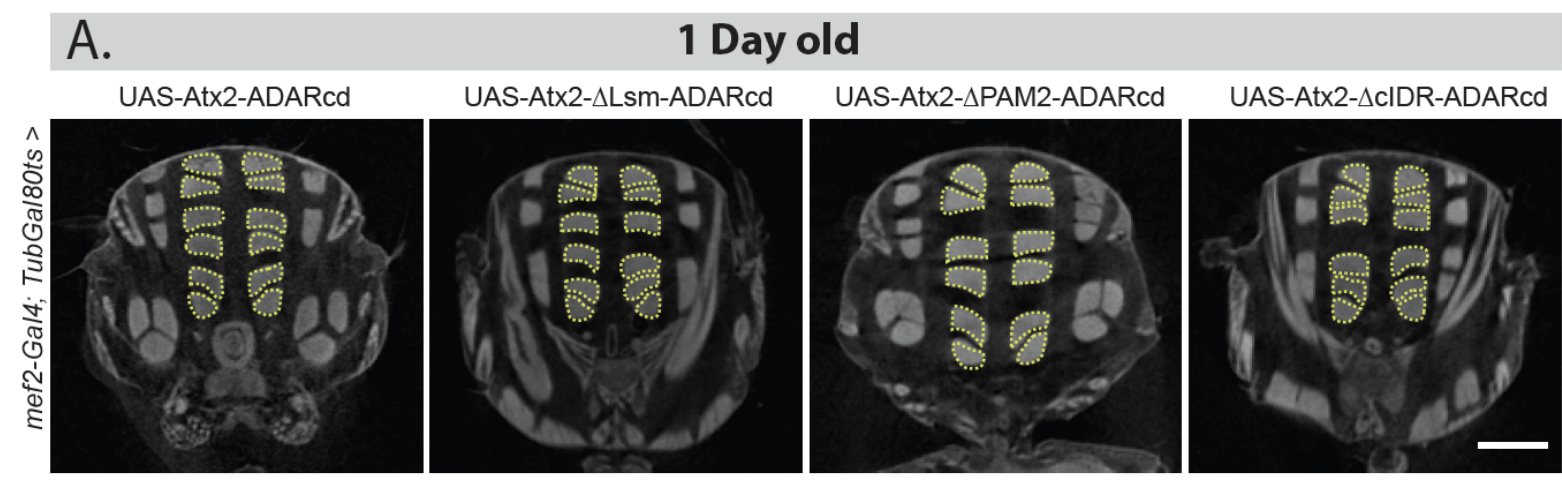

B.

20 Day old

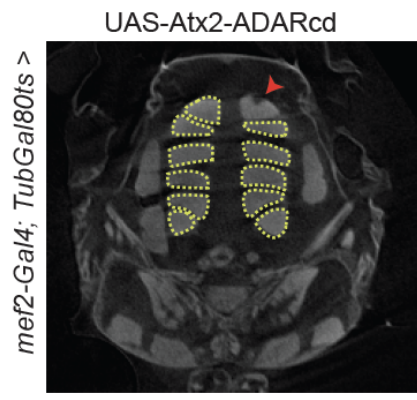

UAS-Atx2-LLsm-ADARcd

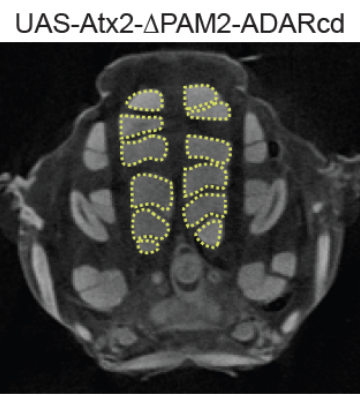

UAS-Atx2-AcIDR-ADARcd
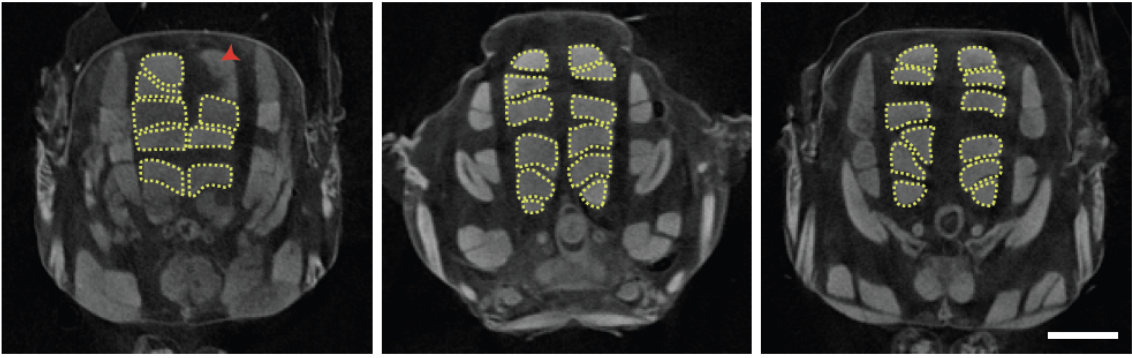

760 Supplementary Figure 4: Transverse view of Drosophila indirect flight muscle imaged using

761 micro-CT show cellular toxicity. (A) Driving UAS-transgene (Atx2WT, Atx2 $\Delta$ cIDR,

762 Atx $2 \Delta \mathrm{PAM}$ or Atx $2 \Delta \mathrm{LSm}$ ) with mef2-Gal4 show normal muscles on day 1. (B) Expression of

763 wild-type and Atx $2 \Delta \mathrm{LSm}$ transgene for 20 days show loss of muscle fibers, indicated with

764 solid red arrowheads. Expression of Atx2 $\triangle \mathrm{PAM} 2$ and Atx $2 \Delta \mathrm{cIDR}$ for 20 days show no visible

765 phenotype. 
Supplementary Table 1:

\begin{tabular}{|c|c|c|c|c|c|c|c|c|}
\hline \multirow{2}{*}{ S.NO } & \multirow{2}{*}{ Sample Name } & \multicolumn{2}{|c|}{$\begin{array}{l}\text { Million reads } \\
\text { (Paired end) }\end{array}$} & \multirow{2}{*}{$\begin{array}{c}\text { Total Number } \\
\text { of Million } \\
\text { reads }\end{array}$} & \multirow{2}{*}{$\%>=Q 30$} & \multirow{2}{*}{$\begin{array}{c}\text { Mean } \\
\text { Quality } \\
\text { Score }\end{array}$} & \multirow{2}{*}{$\begin{array}{c}\text { Mapping Percentage } \\
\text { Read } 1\end{array}$} & \multirow{2}{*}{$\begin{array}{c}\text { Mapping Percentage } \\
\text { Read } 2\end{array}$} \\
\hline & & Read 1 & Read 2 & & & & & \\
\hline 1 & Atx2 $\triangle$ PAM2-ADARcd rep_1 & 23.75 & 23.75 & 47 & 97.04 & 38.26 & $92.20 \%$ & $92.10 \%$ \\
\hline 2 & Atx2 $\triangle$ PAM2-ADARcd rep_2 & 22.66 & 22.66 & 45 & 97.03 & 38.26 & $91.30 \%$ & $91.20 \%$ \\
\hline
\end{tabular}

Supplementary Table 2: The targets common between Atx2 wild-type and del-PAM2 are

\section{2 shown in bold text.}

\begin{tabular}{|c|c|c|c|c|c|c|c|}
\hline $\mathrm{Chr}$ & Start & End & Genes & $\begin{array}{c}\text { Replicate } 1 \\
\text { edit } \\
\text { percentage }\end{array}$ & $\begin{array}{c}\text { Replicate } 2 \\
\text { edit } \\
\text { percentage }\end{array}$ & $\begin{array}{c}\text { Average } \\
\text { edit } \\
\text { percentage }\end{array}$ & Chr_coordinate \\
\hline $\operatorname{chr} 2 L$ & 1009080 & 1009081 & IA-2 & 17.1 & 15.5 & 16.3 & chr2L_1009081_IA-2 \\
\hline $\operatorname{chr} 2 L$ & 1009440 & 1009441 & IA-2 & 31.7 & 38.8 & 35.25 & chr2L_1009441_IA-2 \\
\hline $\operatorname{chr} 2 L$ & 1011482 & 1011483 & IA-2 & 31.7 & 34.7 & 33.2 & chr2L_1011483_IA-2 \\
\hline $\operatorname{chr} 2 \mathrm{~L}$ & 13505104 & 13505105 & B4 & 22.4 & 17.48 & 19.94 & chr2L_13505105 B4 \\
\hline $\operatorname{chr} 2 L$ & 17188307 & 17188308 & beat-IIIc & 18 & 21.7 & 19.85 & chr2L_17188308_beat-IIIc \\
\hline chr2L & 19746161 & 19746162 & CG10631 & 25.65 & 19.4 & 22.52 & chr2L_19746162_CG10631 \\
\hline chr2L & 20056018 & 20056019 & SNPF & 16 & 24.3 & 20.15 & chr2L_20056019_sNPF \\
\hline $\operatorname{chr} 2 \mathrm{~L}$ & 7891375 & 7891376 & Snoo & 18.5 & 16.7 & 17.6 & chr2L_7891376_Snoo \\
\hline $\operatorname{chr} 2 \mathrm{~L}$ & 8113160 & 8113161 & Bsg & 17.4 & 19.05 & 18.23 & chr2L_8113161_Bsg \\
\hline $\operatorname{chr} 2 L$ & 8113894 & 8113895 & Bsg & 16.82 & 28.7 & 22.76 & chr2L_8113895_Bsg \\
\hline $\operatorname{chr} 2 \mathrm{~L}$ & 8116005 & 8116006 & Bsg & 18.2 & 27.4 & 22.8 & chr2L_8116006_Bsg \\
\hline $\operatorname{chr} 2 \mathrm{~L}$ & 9256901 & 9256902 & Ggamma30A & 19.5 & 32.6 & 26.05 & chr2L_9256902_Ggamma30A \\
\hline $\operatorname{chr} 2 \mathrm{~L}$ & 9292530 & 9292531 & Ggamma30A & 42 & 54.4 & 48.2 & chr2L_9292531_Ggamma30A \\
\hline $\operatorname{chr} 2 L$ & 9292829 & 9292830 & Ggamma30A & 42.6 & 53.55 & 48.08 & chr2L_9292830_Ggamma30A \\
\hline chr2L & 9295031 & 9295032 & Ggamma30A & 23.5 & 26 & 24.75 & chr2L 9295032_Ggamma30A \\
\hline chr2R & 12085463 & 12085464 & jeb & 16 & 28.4 & 22.2 & chr2R_12085464_jeb \\
\hline chr2R & 13513577 & 13513578 & Vmat & 64.2 & 63.9 & 64.05 & chr2R_13513578_Vmat \\
\hline chr2R & 13513654 & 13513655 & Vmat & 27.7 & 33.45 & 30.58 & chr2R_13513655_Vmat \\
\hline chr2R & 13513732 & 13513733 & Vmat & 24 & 29.75 & 26.88 & chr2R_13513733_Vmat \\
\hline chr2R & 13513762 & 13513763 & Vmat & 44.55 & 47.3 & 45.92 & chr2R_13513763_Vmat \\
\hline $\operatorname{chr} 2 R$ & 13514350 & 13514351 & Vmat & 37.7 & 38.5 & 38.1 & chr2R_13514351_Vmat \\
\hline chr2R & 13519080 & 13519081 & Vmat & 18.1 & 20.8 & 19.45 & chr2R_13519081_Vmat \\
\hline chr2R & 23690701 & 23690702 & Pal2 & $\mathbf{1 7 . 3}$ & $\mathbf{1 7 . 2}$ & $\mathbf{1 7 . 2 5}$ & chr2R_23690702_Pal2 \\
\hline $\operatorname{chr} 2 \mathrm{R}$ & 24213943 & 24213944 & CG30419 & 27.8 & 22.98 & 25.39 & chr2R_24213944_CG30419 \\
\hline chr2R & 24214234 & 24214235 & CG30419 & 24.2 & 26.1 & 25.15 & chr2R_24214235_CG30419 \\
\hline chr2R & 24214648 & 24214649 & CG30419 & 16.4 & 15.9 & 16.15 & chr2R_24214649_CG30419 \\
\hline $\operatorname{chr} 2 \mathrm{R}$ & 24215193 & 24215194 & CG30419 & 43.5 & 29.7 & 36.6 & chr2R_24215194_CG30419 \\
\hline chr2R & 24229341 & 24229342 & CG30419 & 20.8 & 16.3 & 18.55 & chr2R 24229342_CG30419 \\
\hline chr2R & 6914804 & 6914805 & CG30158 & 16.4 & 16 & 16.2 & chr2R_6914805_CG30158 \\
\hline chr2R & 6920815 & 6920816 & CG30158 & 33.92 & 40.48 & 37.2 & chr2R_6920816_CG30158 \\
\hline chr2R & 6921435 & 6921436 & CG30158 & $\mathbf{1 7 . 5}$ & 41.9 & 29.7 & chr2R_6921436_CG30158 \\
\hline chr2R & 6921976 & 6921977 & CG30158 & 36 & 40.2 & 38.1 & chr2R_6921977_CG30158 \\
\hline chr2R & 7718070 & 7718071 & CG18812 & 15.9 & 19.7 & 17.8 & chr2R_7718071_CG18812 \\
\hline
\end{tabular}


bioRxiv preprint doi: https://doi.org/10.1101/2022.02.15.480566; this version posted February 17, 2022. The copyright holder for this preprint (which was not certified by peer review) is the author/funder, who has granted bioRxiv a license to display the preprint in perpetuity. It is made available under aCC-BY-NC-ND 4.0 International license.

\begin{tabular}{|c|c|c|c|c|c|c|c|}
\hline chr2R & 9473772 & 9473773 & Camta & 21.75 & 30.18 & 25.96 & chr2R_9473773_Camta \\
\hline $\operatorname{chr} 2 \mathrm{R}$ & 9479421 & 9479422 & Camta & 23.1 & 26 & 24.55 & chr2R_9479422_Camta \\
\hline chr2R & 9480019 & 9480020 & Camta & 32 & 41 & 36.5 & chr2R_9480020_Camta \\
\hline chr2R & 9910328 & 9910329 & FMRFa & 42.5 & 25 & 33.75 & chr2R_9910329_FMRFa \\
\hline chr3L & 11498209 & 11498210 & chrb & 15.82 & 20.5 & 18.16 & chr3L_11498210_chrb \\
\hline $\operatorname{chr} 3 \mathrm{~L}$ & 12267895 & 12267896 & CG32100 & 20 & 16.1 & 18.05 & chr3L_12267896_CG32100 \\
\hline $\operatorname{chr} 3 \mathrm{~L}$ & 1504295 & 1504296 & Psa & 18.6 & 15.9 & 17.25 & chr3L_1504296_Psa \\
\hline $\operatorname{chr} 3 \mathrm{~L}$ & 1521650 & 1521651 & Psa & 18.5 & 34.6 & 26.55 & chr3L_1521651_Psa \\
\hline $\operatorname{chr} 3 \mathrm{~L}$ & 1543675 & 1543676 & CG7852 & 15.5 & 22 & 18.75 & chr3L_1543676_CG7852 \\
\hline $\operatorname{chr} 3 \mathrm{~L}$ & 17062355 & 17062356 & Rbp6 & 15.2 & 18.5 & 16.85 & chr3L_17062356_Rbp6 \\
\hline $\operatorname{chr} 3 \mathrm{~L}$ & 17147382 & 17147383 & Rbp6 & 18.23 & 26.62 & 22.42 & chr3L_17147383_Rbp6 \\
\hline $\operatorname{chr} 3 \mathrm{~L}$ & 17345219 & 17345220 & Mip & 29.9 & 27.2 & 28.55 & chr3L_17345220_Mip \\
\hline chr3L & 17345290 & 17345291 & Mip & 17.9 & 16.9 & $\mathbf{1 7 . 4}$ & chr3L_17345291_Mip \\
\hline $\operatorname{chr} 3 \mathrm{~L}$ & 19066983 & 19066984 & Mkp3 & 18.9 & 15.7 & $\mathbf{1 7 . 3}$ & chr3L_19066984_Mkp3 \\
\hline $\operatorname{chr} 3 \mathrm{~L}$ & 21494821 & 21494822 & $\mathrm{Hr} 78$ & 27.1 & 18.4 & 22.75 & chr3L_21494822_Hr78 \\
\hline $\operatorname{chr} 3 \mathrm{~L}$ & 21831417 & 21831418 & CG7148 & 15.8 & 28.6 & 22.2 & chr3L 21831418_CG7148 \\
\hline $\operatorname{chr} 3 \mathrm{~L}$ & 21930851 & 21930852 & mub & 15 & 17.2 & 16.1 & chr3L $21930852 \mathrm{mub}$ \\
\hline $\operatorname{chr} 3 \mathrm{~L}$ & 21931110 & 21931111 & mub & 15.1 & 20.1 & 17.6 & chr3L_21931111_mub \\
\hline $\operatorname{chr} 3 \mathrm{~L}$ & 22061206 & 22061207 & Oct-TyrR & 15.4 & 16.7 & 16.05 & chr3L_22061207_Oct-TyrR \\
\hline $\operatorname{chr} 3 \mathrm{~L}$ & 22877661 & 22877662 & Chro & 35.3 & 45.7 & 40.5 & chr3L_22877662_Chro \\
\hline $\operatorname{chr} 3 \mathrm{~L}$ & 23148124 & 23148125 & CG32350 & 27.4 & 35.3 & 31.35 & chr3L 23148125_CG32350 \\
\hline $\operatorname{chr} 3 \mathrm{~L}$ & 23747549 & 23747550 & CG17698 & 40.27 & 28.95 & 34.61 & chr3L_23747550_CG17698 \\
\hline $\operatorname{chr} 3 \mathrm{~L}$ & 23934990 & 23934991 & CG40470 & 23.5 & 22.05 & 22.77 & chr3L_23934991_CG40470 \\
\hline $\operatorname{chr} 3 \mathrm{~L}$ & 3910071 & 3910072 & Eip63F-1 & 20 & 24.5 & 22.25 & chr3L_3910072_Eip63F-1 \\
\hline $\operatorname{chr} 3 \mathrm{~L}$ & $\mathbf{3 9 5 4 3 3 8}$ & 3954339 & CG12605 & 35.2 & 40.8 & 38 & chr3L_3954339_CG12605 \\
\hline $\operatorname{chr} 3 \mathrm{~L}$ & 3954933 & 3954934 & CG12605 & 35.42 & 51.1 & 43.26 & chr3L_3954934_CG12605 \\
\hline $\operatorname{chr} 3 \mathrm{~L}$ & 3957068 & 3957069 & CG12605 & 21.8 & 26.7 & 24.25 & chr3L_3957069_CG12605 \\
\hline $\operatorname{chr} 3 \mathrm{~L}$ & 3957671 & 3957672 & CG12605 & 18.9 & 22.2 & 20.55 & chr3L_3957672_CG12605 \\
\hline $\operatorname{chr} 3 \mathrm{~L}$ & 3961590 & 3961591 & CG12605 & 18.3 & 18.5 & 18.4 & chr3L_3961591_CG12605 \\
\hline $\operatorname{chr} 3 \mathrm{~L}$ & 3992789 & 3992790 & scrt & 21.08 & 27.28 & 24.18 & chr3L_3992790_scrt \\
\hline $\operatorname{chr} 3 \mathrm{~L}$ & 4092142 & 4092143 & CG14989 & 15.88 & 18.6 & 17.24 & chr3L_4092143_CG14989 \\
\hline $\operatorname{chr} 3 \mathrm{~L}$ & 4113123 & 4113124 & Ack & 18.4 & 16.7 & 17.55 & chr3L_4113124_Ack \\
\hline $\operatorname{chr} 3 \mathrm{~L}$ & 4113297 & 4113298 & Ack & 18.4 & 17.9 & 18.15 & chr3L_4113298_Ack \\
\hline $\operatorname{chr} 3 \mathrm{~L}$ & 572527 & 572528 & hipk & 29.8 & 31 & 30.4 & chr3L_572528_hipk \\
\hline $\operatorname{chr} 3 \mathrm{~L}$ & 572530 & 572531 & hipk & 42.7 & 43 & 42.85 & chr3L_572531_hipk \\
\hline $\operatorname{chr} 3 \mathrm{~L}$ & $\mathbf{5 7 5 7 1 2}$ & 575713 & hipk & 36.12 & 52.92 & 44.52 & chr3L_575713_hipk \\
\hline $\operatorname{chr} 3 \mathrm{~L}$ & $\mathbf{5 7 5 7 5 3}$ & 575754 & hipk & 31.7 & 49.6 & 40.65 & chr3L_575754_hipk \\
\hline $\operatorname{chr} 3 \mathrm{~L}$ & 576730 & 576731 & hipk & 17.1 & 15.2 & 16.15 & chr3L_576731 hipk \\
\hline $\operatorname{chr} 3 \mathrm{~L}$ & 577020 & 577021 & hipk & 20 & 16.9 & 18.45 & chr3L_577021_hipk \\
\hline $\operatorname{chr} 3 \mathrm{~L}$ & $\mathbf{5 7 7 4 1 7}$ & 577418 & hipk & 51.42 & 62.12 & 56.77 & chr3L_577418_hipk \\
\hline $\operatorname{chr} 3 \mathrm{~L}$ & 577970 & 577971 & hipk & 21.4 & 25.9 & 23.65 & chr3L_577971_hipk \\
\hline $\operatorname{chr} 3 \mathrm{~L}$ & 578186 & 578187 & hipk & 18.2 & 24.9 & 21.55 & chr3L_578187_hipk \\
\hline $\operatorname{chr} 3 \mathrm{~L}$ & 578453 & 578454 & hipk & 25.7 & 32.7 & 29.2 & chr3L_578454_hipk \\
\hline $\operatorname{chr} 3 \mathrm{~L}$ & 579335 & 579336 & hipk & 18.1 & 17 & 17.55 & chr3L_579336_hipk \\
\hline $\operatorname{chr} 3 \mathrm{~L}$ & 579634 & 579635 & hipk & 20.5 & 19.8 & 20.15 & chr3L 579635 hipk \\
\hline
\end{tabular}




\begin{tabular}{|c|c|c|c|c|c|c|c|}
\hline chr3L & 580103 & 580104 & hipk & 63.1 & 67.7 & 65.4 & chr3L_580104_hipk \\
\hline $\operatorname{chr} 3 \mathrm{~L}$ & 580500 & 580501 & hipk & 15.6 & 18.1 & 16.85 & chr3L_580501_hipk \\
\hline chr3L & 580932 & 580933 & hipk & 17.9 & 24.1 & 21 & chr3L 580933 hipk \\
\hline $\operatorname{chr} 3 \mathrm{~L}$ & 8970787 & 8970788 & CG5026 & 17.9 & 16.7 & $\mathbf{1 7 . 3}$ & chr3L_8970788_CG5026 \\
\hline $\operatorname{chr} 3 \mathrm{~L}$ & 8993382 & 8993383 & smg & 25.9 & 15.3 & 20.6 & chr3L_8993383_smg \\
\hline $\operatorname{chr} 3 \mathrm{~L}$ & 9074752 & 9074753 & Tequila & 29.8 & 19.5 & 24.65 & chr3L_9074753_Tequila \\
\hline chr3L & 9103274 & 9103275 & bol & 23.9 & 26.3 & 25.1 & chr3L_9103275_bol \\
\hline $\operatorname{chr} 3 \mathrm{~L}$ & 9136454 & 9136455 & Use1 & 25 & 16 & 20.5 & chr3L_9136455_Use1 \\
\hline $\operatorname{chr} 3 \mathrm{~L}$ & 9669496 & 9669497 & fry & 18.2 & 18.2 & 18.2 & chr3L 9669497 fry \\
\hline $\operatorname{chr} 3 \mathrm{~L}$ & 9945905 & 9945906 & CG34356 & 19.4 & 32.1 & 25.75 & chr3L_9945906_CG34356 \\
\hline $\operatorname{chr} 3 \mathrm{R}$ & 10158991 & 10158992 & Invadolysin & 17.9 & 18.2 & 18.05 & chr3R_10158992_Invadolysin \\
\hline chr3R & 10862820 & 10862821 & CG6574 & 20.8 & 33.3 & 27.05 & chr3R_10862821_CG6574 \\
\hline chr3R & 10877257 & 10877258 & CR45195 & 32.7 & 19.5 & 26.1 & chr3R_10877258_CR45195 \\
\hline $\operatorname{chr} 3 \mathrm{R}$ & 10889941 & 10889942 & Leash & 18.2 & 18.8 & 18.5 & chr3R_10889942_Leash \\
\hline chr3R & 13224637 & 13224638 & Ace & 24.8 & 33.3 & 29.05 & chr3R_13224638_Ace \\
\hline chr3R & 13227870 & 13227871 & Ace & 26.6 & 35.3 & 30.95 & chr3R_13227871_Ace \\
\hline chr3R & 13227970 & 13227971 & Ace & 33.42 & 47.95 & 40.69 & chr3R_13227971_Ace \\
\hline $\operatorname{chr} 3 \mathrm{R}$ & 14330745 & 14330746 & NK7.1 & 16.2 & 16.7 & 16.45 & chr3R_14330746_NK7.1 \\
\hline $\operatorname{chr} 3 \mathrm{R}$ & 14660839 & 14660840 & Hexim & 17.1 & 20 & 18.55 & chr3R_14660840_Hexim \\
\hline chr3R & 14669984 & 14669985 & Meltrin & 16.95 & 20.7 & 18.82 & chr3R_14669985_Meltrin \\
\hline $\operatorname{chr} 3 \mathrm{R}$ & 14746335 & 14746336 & jvl & 36.4 & 20.9 & 28.65 & chr3R_14746336_jvl \\
\hline $\operatorname{chr} 3 \mathrm{R}$ & 14746546 & 14746547 & smp-30 & 45.1 & 24 & 34.55 & chr3R_14746547_smp-30 \\
\hline chr3R & 14804349 & 14804350 & btsz & 16.5 & 26.5 & 21.5 & chr3R_14804350_btsz \\
\hline chr3R & 15255687 & 15255688 & CG42404 & 18.2 & $\mathbf{1 7 . 6}$ & 17.9 & chr3R_15255688_CG42404 \\
\hline $\operatorname{chr} 3 \mathrm{R}$ & 15356475 & 15356476 & $\operatorname{Atg} 4 b$ & 15.4 & 20.7 & 18.05 & chr3R_15356476_Atg4b \\
\hline $\operatorname{chr} 3 \mathrm{R}$ & 15414730 & 15414731 & Atx2 & 22.82 & 26.25 & 24.54 & chr3R_15414731_Atx2 \\
\hline $\operatorname{chr} 3 \mathrm{R}$ & 15414731 & 15414732 & Atx2 & 19 & 22.6 & 20.8 & chr3R_15414732_Atx2 \\
\hline chr3R & 15849417 & 15849418 & cv-d & 18.8 & 22.2 & 20.5 & chr3R_15849418_cv-d \\
\hline chr3R & 16611267 & 16611268 & NPF & 22.98 & 23.52 & 23.25 & chr3R_16611268_NPF \\
\hline chr3R & 16645743 & 16645744 & CG10324 & 26.1 & 35 & 30.55 & chr3R_16645744_CG10324 \\
\hline $\operatorname{chr} 3 \mathrm{R}$ & 17090737 & 17090738 & cal1 & 25 & 15.4 & 20.2 & chr3R_17090738_cal1 \\
\hline chr3R & 17731884 & 17731885 & Lgr1 & 20 & 19 & 19.5 & chr3R_17731885_Lgr1 \\
\hline $\operatorname{chr} 3 \mathrm{R}$ & 17802763 & 17802764 & CG17806 & 20.7 & 18.8 & 19.75 & chr3R 17802764_CG17806 \\
\hline $\operatorname{chr} 3 \mathrm{R}$ & 19155252 & 19155253 & CG11779 & 15.6 & 19.1 & 17.35 & chr3R_19155253_CG11779 \\
\hline $\operatorname{chr} 3 \mathrm{R}$ & 20783186 & 20783187 & Syp & 21.1 & 17 & 19.05 & chr3R_20783187_Syp \\
\hline $\operatorname{chr} 3 \mathrm{R}$ & 20797469 & 20797470 & Syp & 15.3 & 20 & 17.65 & chr3R_20797470_Syp \\
\hline $\operatorname{chr} 3 \mathrm{R}$ & 20820785 & 20820786 & CG17271 & 31.2 & 19.75 & 25.48 & chr3R_20820786_CG17271 \\
\hline $\operatorname{chr} 3 \mathrm{R}$ & 20862212 & 20862213 & CG3822 & 17 & 26.3 & 21.65 & chr3R_20862213_CG3822 \\
\hline $\operatorname{chr} 3 \mathrm{R}$ & 20992668 & 20992669 & Calx & 17.8 & 27.5 & 22.65 & chr3R 20992669 Calx \\
\hline $\operatorname{chr} 3 \mathrm{R}$ & 21213891 & 21213892 & $\begin{array}{l}\text { SNF4Agamm } \\
\text { a }\end{array}$ & 17.2 & 20 & 18.6 & $\begin{array}{l}\text { chr3R_21213892_SNF4Agamm } \\
\text { a }\end{array}$ \\
\hline $\operatorname{chr} 3 \mathrm{R}$ & 21354284 & 21354285 & $\bmod (\operatorname{mdg} 4)$ & 15 & 19 & 17 & chr3R_21354285_mod(mdg4) \\
\hline chr3R & 21527750 & 21527751 & CG7956 & 30.3 & 26.5 & 28.4 & chr3R 21527751_CG7956 \\
\hline $\operatorname{chr} 3 \mathrm{R}$ & 21625731 & 21625732 & E2f & 18 & 23.7 & 20.85 & chr3R_21625732_E2f \\
\hline $\operatorname{chr} 3 \mathrm{R}$ & 23261698 & 23261699 & orb & 15.2 & 16.1 & 15.65 & chr3R_23261699_orb \\
\hline
\end{tabular}




\begin{tabular}{|c|c|c|c|c|c|c|c|}
\hline chr3R & 23681818 & 23681819 & eIF-3p66 & 20.4 & 21.5 & 20.95 & chr3R_23681819_eIF-3p66 \\
\hline chr3R & 23698883 & 23698884 & prt & 15.4 & 23.4 & 19.4 & chr3R_23698884_prt \\
\hline chr3R & 23723418 & 23723419 & CG10365 & 16.1 & 21.1 & 18.6 & chr3R_23723419_CG10365 \\
\hline chr3R & 23732353 & 23732354 & Rpn9 & 20.4 & 16.7 & 18.55 & chr3R 23732354_Rpn9 \\
\hline $\operatorname{chr} 3 \mathrm{R}$ & 24664388 & 24664389 & slo & 23.1 & 30 & 26.55 & chr3R_24664389_slo \\
\hline $\operatorname{chr} 3 \mathrm{R}$ & 24802164 & 24802165 & polybromo & 29.2 & 20.98 & 25.09 & chr3R_24802165_polybromo \\
\hline chr3R & 24820485 & 24820486 & Saf-B & 15 & 22 & 18.5 & chr3R_24820486_Saf-B \\
\hline $\operatorname{chr} 3 \mathrm{R}$ & 25234647 & 25234648 & CG10420 & 22.2 & 34.5 & 28.35 & chr3R 25234648_CG10420 \\
\hline chr3R & 26233920 & 26233921 & CG12290 & 25.6 & 18.4 & 22 & chr3R_26233921_CG12290 \\
\hline chr3R & 28050111 & 28050112 & CG34362 & 15.6 & 25.6 & 20.6 & chr3R_28050112_CG34362 \\
\hline chr3R & 28838531 & 28838532 & Apc & 20.4 & 18.8 & 19.6 & chr3R_28838532_Apc \\
\hline chr3R & 29659085 & 29659086 & Dop1R2 & 15.8 & 39.5 & 27.65 & chr3R 29659086 Dop1R2 \\
\hline chr3R & 29674515 & 29674516 & Bub3 & 27.6 & $\mathbf{1 7 . 8}$ & 22.7 & chr3R_29674516_Bub3 \\
\hline $\operatorname{chr} 3 \mathrm{R}$ & 31457698 & 31457699 & Gprk2 & 23.5 & 24.5 & 24 & chr3R_31457699_Gprk2 \\
\hline $\operatorname{chr} 3 \mathrm{R}$ & 31841367 & 31841368 & RhoGAP100F & 17.73 & 19 & 18.37 & chr3R_31841368_RhoGAP100F \\
\hline chr3R & 5811503 & 5811504 & CG11000 & 21.3 & 32.4 & 26.85 & chr3R_5811504_CG11000 \\
\hline chr3R & 5811505 & 5811506 & CG11000 & 20.8 & 25.7 & 23.25 & chr3R_5811506_CG11000 \\
\hline chr3R & 7126383 & 7126384 & CG10098 & 18.6 & 19.1 & 18.85 & chr3R_7126384_CG10098 \\
\hline chr3R & 8244435 & 8244436 & CG18749 & 15.4 & 16.1 & 15.75 & chr3R_8244436_CG18749 \\
\hline chr3R & 8244435 & 8244436 & CG33722 & 15.4 & 16.1 & 15.75 & chr3R_8244436_CG33722 \\
\hline chr3R & 9416762 & 9416763 & alpha-Man-II & 30.8 & 32.3 & 31.55 & chr3R_9416763_alpha-Man-II \\
\hline chr3R & 9441505 & 9441506 & ps & 37.92 & 33.52 & 35.72 & chr3R 9441506 ps \\
\hline chr3R & 9471135 & 9471136 & CG16779 & 43.05 & 34.85 & 38.95 & chr3R_9471136_CG16779 \\
\hline chr3R & 9525979 & 9525980 & CG8176 & 16.2 & 24.4 & 20.3 & chr3R_9525980_CG8176 \\
\hline chr3R & 9539464 & 9539465 & mura & 21.75 & 20.05 & 20.9 & chr3R_9539465_mura \\
\hline chr3R & 9794186 & 9794187 & CG8516 & 19.4 & 30.8 & 25.1 & chr3R_9794187_CG8516 \\
\hline $\operatorname{chr} 4$ & 478956 & 478957 & Asator & 15.1 & 20 & 17.55 & chr4_478957_Asator \\
\hline chr4 & 532906 & 532907 & zfh2 & 20 & 19.7 & 19.85 & chr4_532907_zfh2 \\
\hline chr4 & 92946 & 92947 & pan & 22.5 & 20.8 & 21.65 & chr4_92947_pan \\
\hline $\operatorname{chrX}$ & 10309093 & 10309094 & alpha-Man-I & 24.5 & 29 & 26.75 & chrX_10309094_alpha-Man-I \\
\hline $\operatorname{chrX}$ & 12331302 & 12331303 & Ten-a & 34.8 & 34 & 34.4 & chrX_12331303_Ten-a \\
\hline $\operatorname{chrX}$ & 16075472 & 16075473 & Tob & 23.68 & 29.32 & 26.5 & chrX_16075473_Tob \\
\hline $\operatorname{chrX}$ & 16075887 & 16075888 & Tob & 22.2 & 22 & 22.1 & chrX_16075888_Tob \\
\hline $\operatorname{chrX}$ & 16075888 & 16075889 & Tob & 21.6 & 24 & 22.8 & chrX_16075889 Tob \\
\hline $\operatorname{chrX}$ & 16076959 & 16076960 & Tob & 20 & 23.3 & 21.65 & chrX_16076960_Tob \\
\hline $\operatorname{chrX}$ & 16077193 & 16077194 & Tob & 17.85 & 19.15 & 18.5 & chrX_16077194_Tob \\
\hline $\operatorname{chrX}$ & 16089317 & 16089318 & Tob & 15.2 & 16.1 & 15.65 & chrX_16089318_Tob \\
\hline $\operatorname{chrX}$ & 3321068 & 3321069 & dnc & 22.7 & 28.9 & 25.8 & chrX_3321069_dnc \\
\hline $\operatorname{chr} \mathrm{X}$ & 3342369 & 3342370 & dnc & 17.4 & 22.2 & 19.8 & chrX_3342370_dnc \\
\hline chrX & 6325433 & 6325434 & CG15894 & 32 & 20.8 & 26.4 & chrX_6325434_CG15894 \\
\hline $\operatorname{chrX}$ & 9172798 & 9172799 & mei-P26 & $\mathbf{1 7 . 3}$ & 23.1 & 20.2 & chrX_9172799_mei-P26 \\
\hline $\operatorname{chr} \mathrm{X}$ & 9179452 & 9179453 & mei-P26 & 17.35 & 22.23 & 19.79 & chrX 9179453 mei-P26 \\
\hline $\operatorname{chrX}$ & 9188891 & 9188892 & mei-P26 & 15.8 & 18.4 & 17.1 & chrX 9188892 mei-P26 \\
\hline
\end{tabular}


bioRxiv preprint doi: https://doi.org/10.1101/2022.02.15.480566; this version posted February 17, 2022. The copyright holder for this preprint (which was not certified by peer review) is the author/funder, who has granted bioRxiv a license to display the preprint in perpetuity. It is made available under aCC-BY-NC-ND 4.0 International license.

\section{BIBLIOGRAPHY:}

Alberti S, Gladfelter A, Mittag T (2019) Considerations and Challenges in Studying LiquidLiquid Phase Separation and Biomolecular Condensates. Cell 176: 419-434

Alberti S, Mateju D, Mediani L, Carra S (2017) Granulostasis: Protein Quality Control of RNP Granules. Frontiers in Molecular Neuroscience 10

Andrusiak MG, Sharifnia P, Lyu X, Wang Z, Dickey AM, Wu Z, Chisholm AD, Jin Y (2019) Inhibition of Axon Regeneration by Liquid-like TIAR-2 Granules. Neuron 104: 290-304.e298

Ash PEA, Lei S, Shattuck J, Boudeau S, Carlomagno Y, Medalla M, Mashimo BL, Socorro G, Al-Mohanna LFA, Jiang L et al (2021) TIA1 potentiates tau phase separation and promotes generation of toxic oligomeric tau. Proceedings of the National Academy of Sciences 118: e2014188118

Azkanaz M, Rodríguez López A, De Boer B, Huiting W, Angrand P-O, Vellenga E, Kampinga $\mathrm{HH}$, Bergink S, Martens JH, Schuringa JJ et al (2019) Protein quality control in the nucleolus safeguards recovery of epigenetic regulators after heat shock. eLife 8

Babinchak WM, Surewicz WK (2020) Liquid-Liquid Phase Separation and Its Mechanistic Role in Pathological Protein Aggregation. Journal of Molecular Biology 432: 1910-1925

Bah A, Forman-Kay JD (2016) Modulation of Intrinsically Disordered Protein Function by Post-translational Modifications. Journal of Biological Chemistry 291: 6696-6705

Bah A, Vernon RM, Siddiqui Z, Krzeminski M, Muhandiram R, Zhao C, Sonenberg N, Kay LE, Forman-Kay JD (2015) Folding of an intrinsically disordered protein by phosphorylation as a regulatory switch. Nature 519: 106-109

Bakthavachalu B, Huelsmeier J, Sudhakaran IP, Hillebrand J, Singh A, Petrauskas A, Thiagarajan D, Sankaranarayanan M, Mizoue L, Anderson EN et al (2018) RNP-Granule Assembly via Ataxin-2 Disordered Domains Is Required for Long-Term Memory and Neurodegeneration. Neuron 98: 754-766.e754

Becker LA, Huang B, Bieri G, Ma R, Knowles DA, Jafar-Nejad P, Messing J, Kim HJ, Soriano A, Auburger $G$ et al (2017) Therapeutic reduction of ataxin-2 extends lifespan and reduces pathology in TDP-43 mice. Nature 544: 367-371

Berlow RB, Dyson HJ, Wright PE (2015) Functional advantages of dynamic protein disorder. FEBS Lett 589: 2433-2440

Bevilacqua PC, Williams AM, Chou H-L, Assmann SM (2022) RNA multimerization as an organizing force for liquid-liquid phase separation. RNA 28: 16-26

Biogen, 2021. https://clinicaltrials.gov/ct2/show/NCT04494256.

Boeynaems S, Dorone Y, Marian A, Shabardina V, Huang G, Kim G, Sanyal A, Şen N-E, Docampo R, Ruiz-Trillo I et al (2021) Poly(A)-binding protein is an ataxin-2 chaperone that emulsifies biomolecular condensates. bioRxiv: 2021.2008.2023.457426 
Brandmann T, Fakim H, Padamsi Z, Youn JY, Gingras AC, Fabian MR, Jinek M (2018) Molecular architecture of LSM14 interactions involved in the assembly of mRNA silencing complexes. Embo j 37

830

831

Buchan JR (2014) mRNP granules. RNA Biology 11: 1019-1030

832

Calabretta S, Richard S (2015) Emerging Roles of Disordered Sequences in RNA-Binding Proteins. Trends Biochem Sci 40: 662-672

835

Cao X, Jin X, Liu B (2020) The involvement of stress granules in aging and aging-associated diseases. Aging Cell 19

840

Chou A, Krukowski K, Jopson T, Zhu PJ, Costa-Mattioli M, Walter P, Rosi S (2017) Inhibition of the integrated stress response reverses cognitive deficits after traumatic brain injury. Proc Natl Acad Sci U S A 114: E6420-e6426

842

Cirulli ET, Lasseigne BN, Petrovski S, Sapp PC, Dion PA, Leblond CS, Couthouis J, Lu YF, Wang Q, Krueger BJ et al (2015) Exome sequencing in amyotrophic lateral sclerosis identifies risk genes and pathways. Science 347: 1436-1441

Couthouis J, Hart MP, Erion R, King OD, Diaz Z, Nakaya T, Ibrahim F, Kim H-J, MojsilovicPetrovic J, Panossian S et al (2012) Evaluating the role of the FUS/TLS-related gene EWSR1 in amyotrophic lateral sclerosis. Human Molecular Genetics 21: 2899-2911

Damrath E, Heck MV, Gispert S, Azizov M, Nowock J, Seifried C, Rüb U, Walter M, Auburger G (2012) ATXN2-CAG42 Sequesters PABPC1 into Insolubility and Induces FBXW8 in Cerebellum of Old Ataxic Knock-In Mice. PLoS Genetics 8: e1002920

De Graeve F, Besse F (2018) Neuronal RNP granules: from physiological to pathological assemblies. Biological Chemistry 399: 623-635

Decker CJ, Teixeira D, Parker R (2007) Edc3p and a glutamine/asparagine-rich domain of Lsm4p function in processing body assembly in Saccharomyces cerevisiae. J Cell Biol 179: 437-449

861

862

Deo RC, Bonanno JB, Sonenberg N, Burley SK (1999) Recognition of Polyadenylate RNA by the Poly(A)-Binding Protein. Cell 98: 835-845

Elden AC, Kim HJ, Hart MP, Chen-Plotkin AS, Johnson BS, Fang X, Armakola M, Geser F, 866 Greene R, Lu MM et al (2010) Ataxin-2 intermediate-length polyglutamine expansions are associated with increased risk for ALS. Nature 466: 1069-1075

Formicola N, Vijayakumar J, Besse F (2019) Neuronal ribonucleoprotein granules: Dynamic sensors of localized signals. Traffic 20: 639-649

Gilks N, Kedersha N, Ayodele M, Shen L, Stoecklin G, Dember LM, Anderson P (2004) Stress granule assembly is mediated by prion-like aggregation of TIA-1. Mol Biol Cell 15: 5383-5398 
874 Ginsberg SD, Galvin JE, Chiu TS, Lee VM, Masliah E, Trojanowski JQ (1998) RNA sequestration to pathological lesions of neurodegenerative diseases. Acta Neuropathol 96: 487494

Gomes E, Shorter J (2019) The molecular language of membraneless organelles. J Biol Chem 294: 7115-7127

880

Hachet O, Ephrussi A (2004) Splicing of oskar RNA in the nucleus is coupled to its cytoplasmic localization. Nature 428: 959-963

883

Halliday M, Radford H, Zents KAM, Molloy C, Moreno JA, Verity NC, Smith E, Ortori CA, Barrett DA, Bushell M et al (2017) Repurposed drugs targeting eIF2 $\alpha$-P-mediated translational repression prevent neurodegeneration in mice. Brain 140: 1768-1783

Han TW, Kato M, Xie S, Wu LC, Mirzaei H, Pei J, Chen M, Xie Y, Allen J, Xiao G et al (2012) Cell-free formation of RNA granules: bound RNAs identify features and components of cellular assemblies. Cell 149: 768-779

Harlen KM, Churchman LS (2017) The code and beyond: transcription regulation by the RNA polymerase II carboxy-terminal domain. Nature Reviews Molecular Cell Biology 18: 263-273

Hetz C, Zhang K, Kaufman RJ (2020) Mechanisms, regulation and functions of the unfolded protein response. Nature Reviews Molecular Cell Biology 21: 421-438

Hochberg-Laufer H, Schwed-Gross A, Neugebauer KM, Shav-Tal Y (2019) Uncoupling of nucleo-cytoplasmic RNA export and localization during stress. Nucleic Acids Research 47: 4778-4797

Hofweber M, Dormann D (2019) Friend or foe-Post-translational modifications as regulators of phase separation and RNP granule dynamics. Journal of Biological Chemistry 294: 71377150

905

906 Huelsmeier J, Walker E, Bakthavachalu B, Ramaswami M (2021) A C-terminal ataxin-2 disordered region promotes Huntingtin protein aggregation and neurodegeneration in Drosophila models of Huntington's disease. G3 (Bethesda) 11 Review of Cell and Developmental Biology 30: 39-58

Inagaki H, Hosoda N, Tsuiji H, Hoshino S-I (2020) Direct evidence that Ataxin-2 is a translational activator mediating cytoplasmic polyadenylation. Journal of Biological Chemistry 295: 15810-15825

Ivanov P, Kedersha N, Anderson P (2019) Stress Granules and Processing Bodies in Translational Control. Cold Spring Harb Perspect Biol 11 
Järvelin AI, Noerenberg M, Davis I, Castello A (2016) The new (dis)order in RNA regulation.

\section{Cell Commun Signal 14: 9}

926

Jiang S, Fagman JB, Chen C, Alberti S, Liu B (2020) Protein phase separation and its role in tumorigenesis. eLife 9

927

Jiménez-López D, Guzmán P (2014) Insights into the evolution and domain structure of ataxin-

930

931

932 2 proteins across eukaryotes. BMC Research Notes 7: 453

933

934

Kaehler C, Isensee J, Nonhoff U, Terrey M, Hucho T, Lehrach H, Krobitsch S (2012) Ataxin2-like is a regulator of stress granules and processing bodies. PLoS One 7: e50134

935

936

937

938

Kato M, Han TW, Xie S, Shi K, Du X, Wu LC, Mirzaei H, Goldsmith EJ, Longgood J, Pei J et al (2012) Cell-free formation of RNA granules: low complexity sequence domains form dynamic fibers within hydrogels. Cell 149: 753-767

Kedersha N, Anderson P (2007) Mammalian stress granules and processing bodies. Methods Enzymol 431: 61-81

Kedersha N, Panas MD, Achorn CA, Lyons S, Tisdale S, Hickman T, Thomas M, Lieberman J, McInerney GM, Ivanov P et al (2016) G3BP-Caprin1-USP10 complexes mediate stress granule condensation and associate with 40S subunits. J Cell Biol 212: 845-860

Kedersha NL, Gupta M, Li W, Miller I, Anderson P (1999) RNA-Binding Proteins Tia-1 and Tiar Link the Phosphorylation of Eif- $2 \alpha$ to the Assembly of Mammalian Stress Granules. Journal of Cell Biology 147: 1431-1442

Khong A, Parker R (2020) The landscape of eukaryotic mRNPs. RNA 26: 229-239

Kiebler MA, Bassell GJ (2006) Neuronal RNA granules: movers and makers. Neuron 51: 685690

Kim G, Gautier O, Tassoni-Tsuchida E, Ma XR, Gitler AD (2020) ALS Genetics: Gains, Losses, and Implications for Future Therapies. Neuron 108: 822-842

Kim H-J, Raphael AR, Ladow ES, Mcgurk L, Weber RA, Trojanowski JQ, Lee VM-Y, Finkbeiner S, Gitler AD, Bonini NM (2014) Therapeutic modulation of eIF2 $\alpha$ phosphorylation rescues TDP-43 toxicity in amyotrophic lateral sclerosis disease models. Nature Genetics 46: 152-160

Kim HJ, Kim NC, Wang YD, Scarborough EA, Moore J, Diaz Z, MacLea KS, Freibaum B, Li S, Molliex A et al (2013) Mutations in prion-like domains in hnRNPA2B1 and hnRNPA1 cause multisystem proteinopathy and ALS. Nature 495: 467-473

Kim TH, Payliss BJ, Nosella ML, Lee ITW, Toyama Y, Forman-Kay JD, Kay LE (2021) 968 Interaction hot spots for phase separation revealed by NMR studies of a CAPRIN1 condensed phase. Proc Natl Acad Sci U S A 118 
bioRxiv preprint doi: https://doi.org/10.1101/2022.02.15.480566; this version posted February 17, 2022. The copyright holder for this preprint (which was not certified by peer review) is the author/funder, who has granted bioRxiv a license to display the preprint in perpetuity. It is made available under aCC-BY-NC-ND 4.0 International license.

973

974

975

976

977

978

979

980

981

982

983

984

985

986

987

988

989

990

991

992

993

994

995

996

997

998

999

1000

1001

1002

1003

1004

1005

1006

1007

1008

1009

1010

1011

1012

1013

1014

1015

1016

1017

1018

1019

1020

1021

1022

Kozlov G, Safaee N, Rosenauer A, Gehring K (2010) Structural basis of binding of P-bodyassociated proteins GW182 and ataxin-2 by the Mlle domain of poly(A)-binding protein. $J$ Biol Chem 285: 13599-13606

Kwon I, Kato M, Xiang S, Wu L, Theodoropoulos P, Mirzaei H, Han T, Xie S, Corden Jeffry L, McKnight Steven L (2013) Phosphorylation-Regulated Binding of RNA Polymerase II to Fibrous Polymers of Low-Complexity Domains. Cell 155: 1049-1060

Latonen L (2019) Phase-to-Phase With Nucleoli - Stress Responses, Protein Aggregation and Novel Roles of RNA. Frontiers in Cellular Neuroscience 13: 151

Lee J, Yoo E, Lee H, Park K, Hur JH, Lim C (2017) LSM12 and ME31B/DDX6 Define Distinct Modes of Posttranscriptional Regulation by ATAXIN-2 Protein Complex in Drosophila Circadian Pacemaker Neurons. Mol Cell 66: 129-140.e127

Lee KH, Zhang P, Kim HJ, Mitrea DM, Sarkar M, Freibaum BD, Cika J, Coughlin M, Messing J, Molliex A et al (2016) C9orf72 Dipeptide Repeats Impair the Assembly, Dynamics, and Function of Membrane-Less Organelles. Cell 167: 774-788.e717

Li YR, King OD, Shorter J, Gitler AD (2013) Stress granules as crucibles of ALS pathogenesis. J Cell Biol 201: 361-372

Lim C, Allada R (2013) ATAXIN-2 activates PERIOD translation to sustain circadian rhythms in Drosophila. Science 340: 875-879

Lin Y, Currie SL, Rosen MK (2017) Intrinsically disordered sequences enable modulation of protein phase separation through distributed tyrosine motifs. J Biol Chem 292: 19110-19120

Lin Y, Protter SW, David, Rosen K, Michael, Parker R (2015) Formation and Maturation of Phase-Separated Liquid Droplets by RNA-Binding Proteins. Molecular Cell 60: 208-219

Liu EY, Cali CP, Lee EB (2017) RNA metabolism in neurodegenerative disease. Dis Model Mech 10: 509-518

Machida K, Shigeta T, Yamamoto Y, Ito T, Svitkin Y, Sonenberg N, Imataka H (2018) Dynamic interaction of poly(A)-binding protein with the ribosome. Scientific Reports 8: 17435 Mallucci GR, Klenerman D, Rubinsztein DC (2020) Developing Therapies for Neurodegenerative Disorders: Insights from Protein Aggregation and Cellular Stress Responses. Annual Review of Cell and Developmental Biology 36: 165-189

Mandrioli J, Mediani L, Alberti S, Carra S (2020) ALS and FTD: Where RNA metabolism meets protein quality control. Semin Cell Dev Biol 99: 183-192

Mangus DA, Evans MC, Jacobson A (2003) Poly(A)-binding proteins: multifunctional scaffolds for the post-transcriptional control of gene expression. Genome Biol 4: 223

Maniatis T, Reed R (2002) An extensive network of coupling among gene expression machines. Nature 416: 499-506 
bioRxiv preprint doi: https://doi.org/10.1101/2022.02.15.480566; this version posted February 17, 2022. The copyright holder for this preprint (which was not certified by peer review) is the author/funder, who has granted bioRxiv a license to display the preprint in perpetuity. It is made available under aCC-BY-NC-ND 4.0 International license.

Martin KC, Ephrussi A (2009) mRNA localization: gene expression in the spatial dimension. Cell 136: 719-730

Matheny T, Van Treeck B, Huynh TN, Parker R (2021) RNA partitioning into stress granules is based on the summation of multiple interactions. RNA 27: 174-189

McCann C, Holohan EE, Das S, Dervan A, Larkin A, Lee JA, Rodrigues V, Parker R, Ramaswami M (2011) The Ataxin-2 protein is required for microRNA function and synapsespecific long-term olfactory habituation. Proc Natl Acad Sci U S A 108: E655-662

McMahon AC, Rahman R, Jin H, Shen JL, Fieldsend A, Luo W, Rosbash M (2016) TRIBE: Hijacking an RNA-Editing Enzyme to Identify Cell-Specific Targets of RNA-Binding Proteins. Cell 165: 742-753

Murray DT, Kato M, Lin Y, Thurber KR, Hung I, McKnight SL, Tycko R (2017) Structure of FUS Protein Fibrils and Its Relevance to Self-Assembly and Phase Separation of LowComplexity Domains. Cell 171: 615-627.e616

Murthy AC, Dignon GL, Kan Y, Zerze GH, Parekh SH, Mittal J, Fawzi NL (2019) Molecular interactions underlying liquid-liquid phase separation of the FUS low-complexity domain. Nature Structural \& Molecular Biology 26: 637-648

Nonhoff U, Ralser M, Welzel F, Piccini I, Balzereit D, Yaspo ML, Lehrach H, Krobitsch S (2007) Ataxin-2 interacts with the DEAD/H-box RNA helicase DDX6 and interferes with Pbodies and stress granules. Mol Biol Cell 18: 1385-1396

Patel A, Lee HO, Jawerth L, Maharana S, Jahnel M, Hein MY, Stoynov S, Mahamid J, Saha S, Franzmann TM et al (2015) A Liquid-to-Solid Phase Transition of the ALS Protein FUS Accelerated by Disease Mutation. Cell 162: 1066-1077

Preissler S, Ron D (2019) Early Events in the Endoplasmic Reticulum Unfolded Protein Response. Cold Spring Harb Perspect Biol 11

Protter DSW, Parker R (2016) Principles and Properties of Stress Granules. Trends Cell Biol 26: $668-679$

Protter DSW, Rao BS, Van Treeck B, Lin Y, Mizoue L, Rosen MK, Parker R (2018) Intrinsically Disordered Regions Can Contribute Promiscuous Interactions to RNP Granule Assembly. Cell Rep 22: 1401-1412

Ramaswami M, Taylor JP, Parker R (2013) Altered ribostasis: RNA-protein granules in degenerative disorders. Cell 154: 727-736

Rayman JB, Karl KA, Kandel ER (2018) TIA-1 Self-Multimerization, Phase Separation, and Recruitment into Stress Granules Are Dynamically Regulated by Zn2+. Cell Reports 22: 5971

Saito M, Hess D, Eglinger J, Fritsch AW, Kreysing M, Weinert BT, Choudhary C, Matthias P (2019) Acetylation of intrinsically disordered regions regulates phase separation. Nat Chem Biol 15: 51-61 
Satterfield TF, Pallanck LJ (2006) Ataxin-2 and its Drosophila homolog, ATX2, physically assemble with polyribosomes. Hum Mol Genet 15: 2523-2532

Schuller AP, Wojtynek M, Mankus D, Tatli M, Kronenberg-Tenga R, Regmi SG, Dip PV, Lytton-Jean AKR, Brignole EJ, Dasso M et al (2021) The cellular environment shapes the nuclear pore complex architecture. Nature 598: 667-671

Scoles DR, Meera P, Schneider MD, Paul S, Dansithong W, Figueroa KP, Hung G, Rigo F,

Bennett CF, Otis TS et al (2017) Antisense oligonucleotide therapy for spinocerebellar ataxia type 2. Nature 544: 362-366

Shin Y, Brangwynne CP (2017) Liquid phase condensation in cell physiology and disease. Science 357

Shulman JM, Feany MB (2003) Genetic Modifiers of Tauopathy in Drosophila. Genetics 165: 1233-1242

Sidrauski C, Mcgeachy AM, Ingolia NT, Walter P (2015) The small molecule ISRIB reverses the effects of eIF $2 \alpha$ phosphorylation on translation and stress granule assembly. eLife 4

Singh A, Hulsmeier J, Kandi AR, Pothapragada SS, Hillebrand J, Petrauskas A, Agrawal K, and disordered domains in RNP condensation. eLife 10

Strome S, Wood WB (1982) Immunofluorescence visualization of germ-line-specific cytoplasmic granules in embryos, larvae, and adults of Caenorhabditis elegans. Proc Natl Acad Sci U S A 79: 1558-1562

Sudhakaran IP, Hillebrand J, Dervan A, Das S, Holohan EE, Hülsmeier J, Sarov M, Parker R, VijayRaghavan K, Ramaswami M (2014) FMRP and Ataxin-2 function together in long-term olfactory habituation and neuronal translational control. Proc Natl Acad Sci U S A 111: E99E108

Taylor JP, Brown RH, Cleveland DW (2016) Decoding ALS: from genes to mechanism. Nature 539: 197-206

Tillotson R, Selfridge J, Koerner MV, Gadalla KKE, Guy J, De Sousa D, Hector RD, Cobb SR, Bird A (2017) Radically truncated MeCP2 rescues Rett syndrome-like neurological defects. Nature 550: 398-401

Toretsky JA, Wright PE (2014) Assemblages: functional units formed by cellular phase separation. J Cell Biol 206: 579-588

Trapnell C, Pachter L, Salzberg SL (2009) TopHat: discovering splice junctions with RNASeq. Bioinformatics 25: 1105-1111

Van Treeck B, Parker R (2018) Emerging Roles for Intermolecular RNA-RNA Interactions in 
1123 Van Treeck B, Protter DSW, Matheny T, Khong A, Link CD, Parker R (2018) RNA self-

1124

1125

1126

1127

1128

1129

1130

1131

1132

1133

1134

1135

1136

1137

1138

1139

1140

1141

1142

1143

1144

1145

1146

1147

1148

1149

1150

1151

1152

1153

1154

1155

1156

1157

1158

1159

1160

1161

1162

1163

1164

1165

1166

1167

1168

1169

1170

1171

1172 assembly contributes to stress granule formation and defining the stress granule transcriptome.

Proc Natl Acad Sci U S A 115: 2734-2739

Vogler TO, Wheeler JR, Nguyen ED, Hughes MP, Britson KA, Lester E, Rao B, Betta ND, Whitney ON, Ewachiw TE et al (2018) TDP-43 and RNA form amyloid-like myo-granules in regenerating muscle. Nature 563: 508-513

Wang F, Li J, Fan S, Jin Z, Huang C (2020) Targeting stress granules: A novel therapeutic strategy for human diseases. Pharmacological Research 161: 105143

Wheeler JR, Matheny T, Jain S, Abrisch R, Parker R (2016) Distinct stages in stress granule assembly and disassembly. eLife 5

Wolozin B, Ivanov P (2019) Stress granules and neurodegeneration. Nature Reviews Neuroscience 20: 649-666

Wong YL, Lebon L, Edalji R, Lim HB, Sun C, Sidrauski C (2018) The small molecule ISRIB rescues the stability and activity of Vanishing White Matter Disease eIF2B mutant complexes. eLife 7

Xie J, Kozlov G, Gehring K (2014) The "tale" of poly(A) binding protein: the MLLE domain and PAM2-containing proteins. Biochim Biophys Acta 1839: 1062-1068

Yang P, Mathieu C, Kolaitis RM, Zhang P, Messing J, Yurtsever U, Yang Z, Wu J, Li Y, Pan Q et al (2020) G3BP1 Is a Tunable Switch that Triggers Phase Separation to Assemble Stress Granules. Cell 181: 325-345.e328

Yi H, Park J, Ha M, Lim J, Chang H, Kim VN (2018) PABP Cooperates with the CCR4-NOT Complex to Promote mRNA Deadenylation and Block Precocious Decay. Mol Cell 70: 10811088.e1085

Yokoshi M, Li Q, Yamamoto M, Okada H, Suzuki Y, Kawahara Y (2014) Direct binding of Ataxin-2 to distinct elements in 3' UTRs promotes mRNA stability and protein expression. Mol Cell 55: 186-198

Yoshida M, Yoshida K, Kozlov G, Lim NS, De Crescenzo G, Pang Z, Berlanga JJ, Kahvejian A, Gehring K, Wing SS et al (2006) Poly(A) binding protein (PABP) homeostasis is mediated by the stability of its inhibitor, Paip2. The EMBO Journal 25: 1934-1944

Youn JY, Dyakov BJA, Zhang J, Knight JDR, Vernon RM, Forman-Kay JD, Gingras AC (2019) Properties of Stress Granule and P-Body Proteomes. Mol Cell 76: 286-294

Zhang K, Daigle JG, Cunningham KM, Coyne AN, Ruan K, Grima JC, Bowen KE, Wadhwa H, Yang P, Rigo F et al (2018) Stress Granule Assembly Disrupts Nucleocytoplasmic Transport. Cell 173: 958-971.e917

Zhang Y, Ling J, Yuan C, Dubruille R, Emery P (2013) A role for Drosophila ATX2 in activation of PER translation and circadian behavior. Science 340: 879-882 
bioRxiv preprint doi: https://doi.org/10.1101/2022.02.15.480566; this version posted February 17, 2022. The copyright holder for this preprint (which was not certified by peer review) is the author/funder, who has granted bioRxiv a license to display the preprint in perpetuity. It is made available under aCC-BY-NC-ND 4.0 International license.

1173 Zyryanova AF, Kashiwagi K, Rato C, Harding HP, Crespillo-Casado A, Perera LA, Sakamoto 1174 A, Nishimoto M, Yonemochi M, Shirouzu M et al (2021) ISRIB Blunts the Integrated Stress 1175 Response by Allosterically Antagonising the Inhibitory Effect of Phosphorylated eIF2 on 1176 eIF2B. Mol Cell 81: 88-103.e106 